\title{
Limited fibrosis accompanies triple-negative breast cancer metastasis in multiple model systems and is not a preventive target
}

\author{
Danielle Brooks ${ }^{1}$, Alexandra Zimmer ${ }^{1}$, Lalage Wakefield ${ }^{2}$, L. Tiffany Lyle ${ }^{3}$, Simone \\ Difilippantonio ${ }^{4}$, Fabio C. Tucci $^{5}$, Stephane Illiano ${ }^{6}$, Christina M. Annunziata ${ }^{1}$ and \\ Patricia S. Steeg ${ }^{1}$ \\ ${ }^{1}$ Women's Malignancies Branch, Center for Cancer Research, National Cancer Institute, Bethesda, MD, USA \\ ${ }^{2}$ Laboratory of Cancer Biology and Genetics, Center for Cancer Research, National Cancer Institute, Bethesda, MD, USA \\ ${ }^{3}$ Department of Comparative Pathobiology, Purdue University College of Veterinary Medicine, West Lafayette, IN, USA \\ ${ }^{4}$ Laboratory Animal Sciences Program, Leidos Biomedical Research Inc., Frederick National Laboratory for Cancer Research, \\ Frederick, MD, USA \\ ${ }^{5}$ Epigen Biosciences, Inc., San Diego, CA, USA \\ ${ }^{6}$ Sanofi, Chilly Mazarin, France \\ Correspondence to: Patricia S. Steeg, email: steegp@mail.nih.gov
}

Keywords: breast cancer; ovarian cancer; fibrosis; lysophosphatidic acid receptor; metastasis

Received: December 29, $2017 \quad$ Accepted: April 04, $2018 \quad$ Published: May 04, 2018

Copyright: Brooks et al. This is an open-access article distributed under the terms of the Creative Commons Attribution License 3.0 (CC BY 3.0), which permits unrestricted use, distribution, and reproduction in any medium, provided the original author and source are credited.

\section{ABSTRACT}

The lysophosphatidic acid receptor 1 (LPAR1) is mechanistically implicated in both tumor metastasis and tissue fibrosis. Previously, metastasis was increased when fulminant fibrosis was first induced in mice, suggesting a direct connection between these processes. The current report examined the extent of metastasis-induced fibrosis in breast cancer model systems, and tested the metastasis preventive efficacy and fibrosis attenuation of antagonists for LPAR1 and Idiopathic Pulmonary Fibrosis (IPF) in breast and ovarian cancer models. Staining analysis demonstrated only focal, low-moderate levels of fibrosis in lungs from eleven metastasis model systems. Two orally available LPAR1 antagonists, SAR100842 and EPGN9878, significantly inhibited breast cancer motility to LPA in vitro. Both compounds were negative for metastasis prevention and failed to reduce fibrosis in the experimental MDA-MB-231T and spontaneous murine 4T1 in vivo breast cancer metastasis models. SAR100842 demonstrated only occasional reductions in invasive metastases in the SKOV3 and OVCAR5 ovarian cancer experimental metastasis models. Two approved drugs for IPF, nintedanib and pirfenidone, were investigated. Both were ineffective at preventing MDA-MB-231T metastasis, with no attenuation of fibrosis. In summary, metastasisinduced fibrosis is only a minor component of metastasis in untreated progressive breast cancer. LPAR1 antagonists, despite in vitro evidence of specificity and efficacy, were ineffective in vivo as oral agents, as were approved IPF drugs. The data argue against LPAR1 and fibrosis as monotherapy targets for metastasis prevention in triplenegative breast cancer and ovarian cancer. 


\section{INTRODUCTION}

Fibrosis is a chronic wound healing response that has lost normal controls. It is well studied in the lungs (as idiopathic pulmonary fibrosis), the liver, the kidney, and the skin (as systemic scleroderma). After repair of tissue damage, the inflammatory response continues, resulting in the relentless deposition of connective tissue that remodels and destroys normal tissue architecture and function (rev in [1-3]). A key to fibrosis is the permanent activation of myofibroblasts, which express smooth muscle actin $(\alpha-S M A)$ and produce collagen and other extracellular matrix (ECM). Changes in endothelial cells, lymphocytic infiltration and epithelial cells also accompany fibrosis.

The cellular and molecular mechanisms of fibrosis bear an uncanny resemblance to cancer progression (rev in [4]). Shared cell biology characteristics include inflammation, ECM remodeling, proliferation, and the epithelial-mesenchymal transition (EMT). Pathways underlying both processes include TGF- $\beta$ [5], the receptors to the phospholipid lysophosphatidic acid (LPA) [6], PDGF [7], hedgehog [8], integrins [9], chemokines [4], lysyl oxidase [10], etc. A direct connection was proposed in the transdifferentiation of epithelial cancer cells to fibrosis-inducing myofibroblasts via the EMT [11]. When pulmonary fibrosis was induced in mice by either radiation treatment [12] or bleomycin injection [13, 14], tumor metastasis was significantly accelerated. These data provided the experimental foundation for the hypothesis that fibrosis was a mechanistic contributor to cancer progression and a potential therapeutic target. Human tissue studies have also correlated fibrosis with aspects of metastasis including poor patient survival $[15,16]$. Other reports have disagreed, suggesting that fibrosis correlated with better outcome based on changes in immunity [17].

Our previous work centered on the LPA receptor 1 (LPA1). In two breast cancer metastasis models, an LPA $1 / 3$ antagonist had no effect on primary tumor growth but significantly prevented the lung and/or liver metastasis of "triple negative" (estrogen and progesterone receptors, ER and PR, negative; HER2 normal) breast cancer. Tumor cells in the distant site treated with the LPA1 antagonist showed reduced proliferation, suggestive of metastatic dormancy [18]. The LPA axis is mechanistically involved in promoting breast cancer metastasis to other sites, and of other cancer types including ovarian cancer [19-21]. The LPA1 antagonist used in our preclinical studies was not orally available, precipitating a search for orally available, biosimilar antagonists that could be used for maintenance cancer therapy in a clinical trial. Several LPA1 antagonists were identified, all coincidentally in development for fibrosis clinical indications, as supported by preclinical literature [6, 22-24].

In the current manuscript, we have further explored the potential connection between fibrosis and cancer metastasis using triple-negative breast cancer and ovarian cancer model systems. We have asked [1] the extent of fibrosis as a result of metastatic colonization in metastatic colonization in model systems; [2] the effect of orally available LPA1 antagonists on metastasis and fibrosis in triple-negative breast cancer model systems; [3] given the association of LPA receptors and ovarian cancer progression [25-27], the effect of these antagonists in ovarian cancer metastasis, and [4] the effect of recently FDA approved drugs for idiopathic pulmonary fibrosis, pirfenidone [28] and nintedanib [29], in a breast cancer model system. The data point to a conclusion that, distinct from experiments where fulminant fibrosis was first induced by chemical agents or radiation, fibrosis is only focally induced in metastasis, and neither orally available LPA1 antagonists nor FDA approved fibrosis drugs provide significant metastasis prevention.

\section{RESULTS}

\section{Fibrosis in breast cancer metastatic model systems}

We asked the extent of fibrosis that developed when breast cancer cells metastasize to the lungs of experimental animals. Tissue blocks containing H\&E confirmed pulmonary metastatic lesions from ten orthotopic model systems [30] were analyzed for three markers of fibrosisMasson's trichrome, the stain used in histopathology laboratories, collagen I, and $\alpha$-SMA. Representative images are shown on Figure 1. Using trichrome stain, the presence of blue tissue indicated fibrosis. Approximately half of the model systems showed evident fibrotic strands dispersed throughout the section. Succeeding tissue sections were stained for collagen 1 and $\alpha$-SMA. Table 1 presents quantification of the fibrosis staining data by a veterinary pathologist for multiple sections of each model system. IHC staining for molecular subtype and metastatic efficiency data, previously published [30], are listed. We modified the Ashcroft scoring system used for trichrome staining [31], for scoring the models (Supplementary Table 1). On a $0-8$ scale, entirely normal tissue was assigned a score of 0 , and positive scores were based on the predominate pattern within the microscopic sections. Modified Ashcroft scores were compiled for areas within the metastatic lesions as well as the entire lung (Supplementary Figure 1). In the metastatic lesion, scores in the cohort varied from 0-3 (out of 8). Analysis of the entire lung resulted in scores of 4-5 in half of the model systems. Fibrosis is heterogeneously apparent among the model systems tested, and appears more widespread throughout the lungs than confined to the region of the metastatic lesion. In no model was fibrosis "high" ( $\geq 6$ out of 8). Expression of $\alpha$-SMA appeared greater than that of the trichrome histochemical stain for fibrosis or collagen I. In general, the models with the highest degree of fibrosis, tended to also have strong $\alpha$-SMA and collagen I staining, but widespread heterogeneity of markers was observed. 


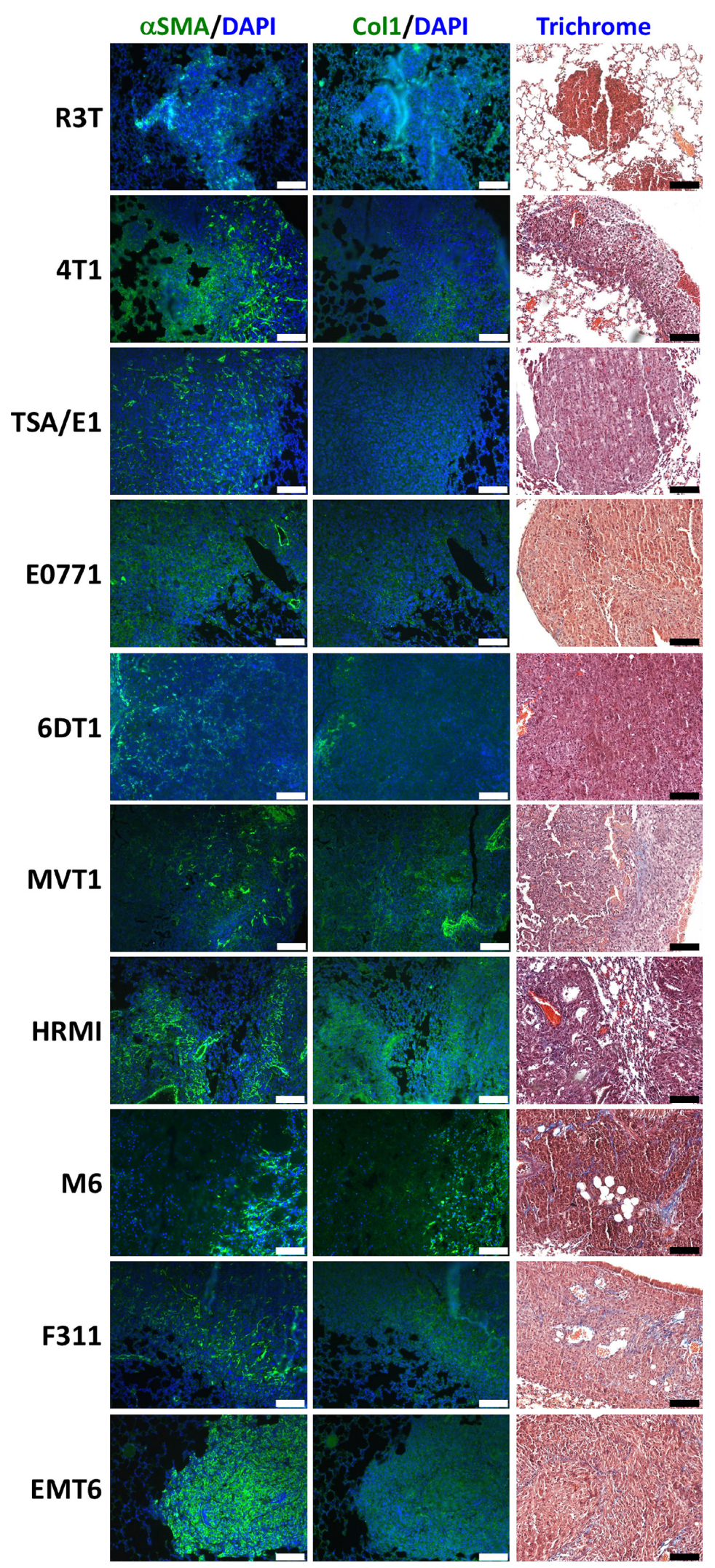

Figure 1: Staining analysis of metastatic lung tissue from ten mouse models of breast cancer. Formalin fixed, paraffin embedded (FFPE) lung tissue sections from metastasis bearing mice were stained for presence and extent of fibrosis. Masson's trichrome stain was used to produce an Ashcroft fibrosis score both within the lung metastases (modified Ashcroft score) and the whole lung. Activated fibroblasts were identified by staining for alpha smooth muscle actin ( $\alpha$ SMA), and the extracellular matrix was assessed by staining for collagen 1 (Col1). Representative images were obtained at $20 \times$ objective and scale bar $=100 \mu \mathrm{m}$. 
Table 1: Summary of immunohistochemical analyses of fibrosis in lung metastases from mouse models of breast cancer $^{\mathrm{a}}$

\begin{tabular}{|c|c|c|c|c|c|c|c|}
\hline \multirow[t]{2}{*}{ Model: } & \multirow[t]{2}{*}{ ER/PR: } & \multirow[t]{2}{*}{ HER2: } & \multirow{2}{*}{$\begin{array}{l}\text { Metastatic } \\
\text { Efficiency: }\end{array}$} & \multicolumn{2}{|c|}{$\begin{array}{l}\text { Modified Ashcroft } \\
\text { Score }^{\mathrm{b}} \text { : }\end{array}$} & \multirow[t]{2}{*}{$\alpha-$ SMA $^{c}:$} & \multirow[t]{2}{*}{ Collagen $I^{\mathrm{c}}$} \\
\hline & & & & Metastasis: & Lung: & & \\
\hline R3T & $-1-$ & $\mathrm{Nl}$ & 60 & 0 & 1 & + & - \\
\hline $4 \mathrm{~T} 1$ & $-1-$ & $\mathrm{N} 1$ & 100 & 1 & 3 & +++ & + \\
\hline TS/A-E1 & $+/-$ & Nl & 100 & 2 & 2 & ++ & - \\
\hline E0771 & $-1-$ & N1 & 50 & 1 & 4 & $+1-$ & + \\
\hline 6DT1 & $-1-$ & $\mathrm{Nl}$ & 90 & 1 & 2 & ++ & ++ \\
\hline Mvt1 & $-1-$ & N1 & 90 & 1 & 3 & ++ & +++ \\
\hline HRM1 & $+1-$ & N1 & 80 & 1 & 5 & ++++ & ++ \\
\hline M6 & $-1-$ & N1 & 55 & 3 & 5 & ++++ & ++++ \\
\hline F3II & $-1-$ & $\mathrm{N} 1$ & 70 & 1 & 5 & ++ & + \\
\hline EMT6 & $+/-$ & $\mathrm{N} 1$ & 100 & 1 & 5 & +++++ & $-1+$ \\
\hline
\end{tabular}

${ }^{a}$ Multiple sections of lung metastases were stained for trichrome, $\alpha$-SMA and collagen I. Model system molecular subtype by immunohistochemistry and metastatic efficiency were previously reported (30).

${ }^{\mathrm{b}}$ See Supplementary Table 1 . Ranges from $0-8$.

'Graded on a - to +++++ scale in intensity.

Given the widespread use of the MDA-MB-231 triple negative breast cancer model system in translational studies, fibrosis levels were assessed (Figure 2). This human cell line produces lung metastases upon tail vein injection into immunocompromised animals [32]. A relatively low modified Ashcroft score was observed for both the metastatic lesion (2.1) and the entire lung (2.5). Prominent $\alpha$-SMA staining and moderate collagen I staining were observed.

\section{LPA1 receptor antagonists as anti-fibrosis agents}

We previously reported that a LPA1 antagonist, Debio 0719 , significantly prevented metastasis in two models of triple negative breast cancer [18]. LPA1 antagonists are in development both as anti-metastatic agents and fibrosis therapeutics [6, 22-24]. As potential breast cancer therapeutics, LPA1 antagonists would be taken on a maintenance schedule and therefore should be orally available. Also, they should be active in an adjuvant model setting, after primary tumor removal. We tested two orally available LPA1 antagonists: SAR100842 [33] (US Patent 8,362,073 B2) was tested clinically in systemic sclerosis (Clinical Trial Identifier NCT01651143); EPGN9878 is in preclinical development (unpublished).

LPA1 protein levels were detectable in multiple breast cancer cell lines (Figure 3A). The triple negative breast cancer cell lines MDA-MB-231T and 4T1-Luc2 were
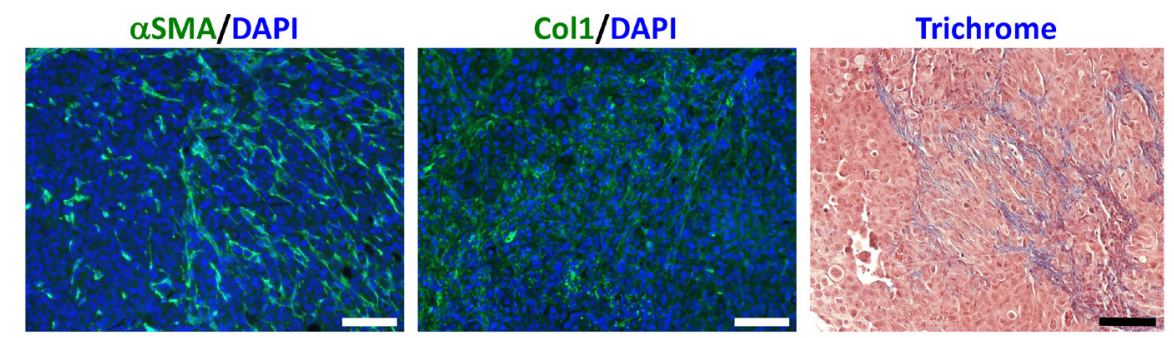

\begin{tabular}{|c|c|c|c|c|c|c|c|c|c|}
\hline Model & $\begin{array}{c}\text { Claudin-low } \\
\text { status }\end{array}$ & $\begin{array}{c}\text { ER } \\
\text { status }\end{array}$ & $\begin{array}{c}\text { PR } \\
\text { status }\end{array}$ & $\begin{array}{c}\text { HER2 } \\
\text { amplified }\end{array}$ & $\begin{array}{c}\text { Metastatic } \\
\text { Efficiency }\end{array}$ & $\begin{array}{c}\text { Metastasis } \\
\text { Ashcroft } \\
\text { Score }\end{array}$ & $\begin{array}{c}\text { aSMA } \\
\text { Staining }\end{array}$ & $\begin{array}{c}\text { Col1 } \\
\text { Staining }\end{array}$ & $\begin{array}{c}\text { Lung } \\
\text { Ashcroft } \\
\text { Score }\end{array}$ \\
\hline $\begin{array}{c}\text { MDA- } \\
\text { MB-231T }\end{array}$ & Low & Neg & Neg & Neg & 100 & 2.1 & +++ & +++ & 2.5 \\
\hline
\end{tabular}

Figure 2: Analysis of fibrosis in metastatic lung tissue from human MDA-MB-231T cells. FFPE lung tissue sections were stained for alpha smooth muscle actin ( $\alpha$ SMA), Collagen 1 (Col1) or Masson's trichrome to quantify fibrosis in lung metastases from this cell line. Characteristics of the model are listed. Images were taken at $20 \times$ objective and scale bar $=100 \mu \mathrm{m}$. 
used to further test the efficacy of SAR100842 in in vitro assays of migration and metastasis. In LPAR1-based in vitro inhibition of LPA-stimulated $\mathrm{Ca}^{++}$flux in a cell based assay, SAR100842 had an $\mathrm{IC}_{50}$ of $65 \mathrm{nM}$; and showed no activity up to $10 \mu \mathrm{M}$ on LPA2, LPA3 or LPA5 in similar calcium assays (data not shown). Increasing doses of SAR100842 did not significantly affect proliferation of either cell line over time (Figure 3B-3C, 3F-3G). However, there was a significant decrease in the ability of cells to migrate in a wound healing assay in a dose dependent manner, 64\% reduction $(p<0.0001)$ with $5 \mu \mathrm{M}$ SAR100842 after 72 hours in MDAMB-231T and $67 \%$ reduction $(p<0.0001)$ with $50 \mu \mathrm{M}$ SAR100842 after 48 hours in 4T1-Luc2 (Figure 3D and 3H). In a Boyden chamber assay for motility, $50 \mu \mathrm{M}$ SAR 100842 reduced the migration of MDA-MD-231T cells through a collagen membrane by 1.92 -fold $(p=0.0004)$ and 3.15 -fold $(p<0.0001)$ to FBS and LPA chemoattractants, respectively (Figure 3E). In 4T1-Luc2 cells $50 \mu \mathrm{M}$ SAR100842 reduced migration by 10.8 -fold $(p=0.01)$ and 13.6-fold $(p=0.007)$ to FBS and LPA, respectively (Figure 3I). The data demonstrate an inhibition of a metastasis and fibrosis associated target at $\mu \mathrm{M}$ concentrations in vitro.

As LPA1 is also associated with ovarian cancer progression [27, 34, 35], three ovarian cancer cell lines were analyzed for LPA1 expression as well (Figure 4A). The SKVO3 line was used for further in vitro analysis. There was no effect with SAR100842 on proliferation over time when compared to vehicle (Figure 4B). There was a 12.8 -fold $(p<0.0001)$ reduction in motility with 10 $\mu \mathrm{M}$ SAR100842 with LPA as a chemoattractant (Figure 4C). Testing of SAR100842 then proceeded to animal models using the same lines.

In the MDA-MB-231T experimental metastasis model system, treatment with SAR100842 showed no difference in total metastasis count (Figure 5A, medians of 83 and 96 in controls and SAR100842, respectively, $p=0.65)$. The median number of large pulmonary metastases ( $>5 \mathrm{~mm}$ ) was lower in SAR100842 treated mice (medians of 4 and 1.5 in controls and SAR100842, respectively) but statistically insignificant ( $p=0.22)$. Masson's trichrome staining of the lungs indicated an increase in fibrosis in SAR100842 treated mice when analyzed by modified Ashcroft scoring $(p=0.02)$. However, no significant change in $\alpha$-SMA staining was observed.

When SAR100842 was dosed in animals bearing 4T1 tumor cells, there was no effect on primary tumor size (Figure 5E, $-8.0 \%$ inhibition in day 2 versus vehicle and $3.5 \%$ inhibition in day 11 versus vehicle, $p=0.42$ ). The number of lung metastases, determined by histological analysis of H\&E stained step sections, was unchanged (Figure 5F, medians of 8.5, 9.3, and 10.6 in the vehicle, day 2 and day 11 treatment groups respectively, $p=0.60$ ). Consistent with the relatively low background levels of fibrosis in the 4T1 model (Table 1), trichrome staining of the lungs from this experiment revealed overall low modified Ashcroft scores that did not vary with treatment (Figure 5G).

The effect of SAR100842 on ovarian cancer metastasis was explored in two model systems, SKOV3 and OVCAR5. The outgrowth of metastatic deposits on tissues, either as surface tumors or invasive lesions, was the primary endpoint (Table 2). In the vehicle control groups, metastatic deposits were common on the surface of multiple organs including the omentum, liver, diaphragm, and peritoneum; invasive lesions were only common in the diaphragm. Ascites were rare. Only a weak reduction in diaphragm, kidney and lymph node metastases was evident in the SKOV3 model treated early with SAR100842; none of these reductions were maintained in the group that started treatment on day 10 post-injection. For the OVCAR5 model, metastases were observed at day 70 post-injection on the omentum, liver, diaphragm, pancreas and peritoneum. Of these, SAR100842 apparently reduced diaphragm tumor deposits, both surface and invasive, but was without significant effect in other locations. Ascites formed with this model, but the numbers were too low for any trend to be apparent.

A second potential LPA1 antagonist is EPGN9878 (US 2016/0024031A1). This orally available LPAR1 antagonist is currently in development for renal fibrosis. In LPAR1-based in vitro inhibition of LPA-stimulated $\mathrm{Ca}^{++}$flux in a cell based assay, EPGN9878 had an $\mathrm{IC}_{50}$ of $8 \mathrm{nM}$; an LPA3 assay showed an $\mathrm{IC}_{50}$ of $>10,000 \mathrm{nM}$. In vivo EPGN has a half-life of $3.5 \mathrm{~h}$ and a $\mathrm{C}_{\max }$ of 859 $\mathrm{ng} / \mathrm{mL}$ after a $20 \mathrm{mg} / \mathrm{kg}$ oral dosing in mice (personal communication, Dr. Fabio Tucci, Epigen Biosciences).

EPGN9878 was first tested in MDA-MB-231T and 4T1-Luc2 cell lines. There was no change in cell viability for either cell line with increasing concentrations of EPGN9878 after 72 hours compared to vehicle (Figure 6A and $6 \mathrm{D})$. In a wound healing assay $5 \mu \mathrm{M}$ of EPGN9878 decreased the migration of cells to close the gap by $72 \%$ $(p<0.0001)$ and 87\% $(p<0.003)$ in MDA-MB-231T cells at 72 hours and 4T1-Luc2 cells at 48 hours, respectively (Figure 6B and 6E). In MDA-MB-231T cells motility in a Boyden chamber assay was reduced by 5.7-fold to FBS and 2.3-fold to LPA chemoattractants with $5 \mu \mathrm{M}$ EPGN9878 (Figure 6C, $p<0.0001$ ). Similar results were seen in 4T1-Luc2 cells with a reduction in motility of 5.7-fold and 4.5-fold (Figure 6F, $p<0.0001$ ). These data provided evidence of LPA signaling inhibition in motility in vitro.

In the MDA-MB-231 experimental metastasis model, total surface lung metastases were comparable between control and EPGN9878 treated groups (Figure 7A, medians of 218 and 215, $p=0.60$ ). A trend toward reduced large metastases $(>5 \mathrm{~mm})$ was observed, with a median of 2.5 large metastases in the control arm and 0 in the EPGN9878 arm (Figure 7B, $p=0.09$ ). No differences in lung fibrosis were observed using Masson's trichrome or $\alpha$-SMA staining (Figure 7C-7D). 

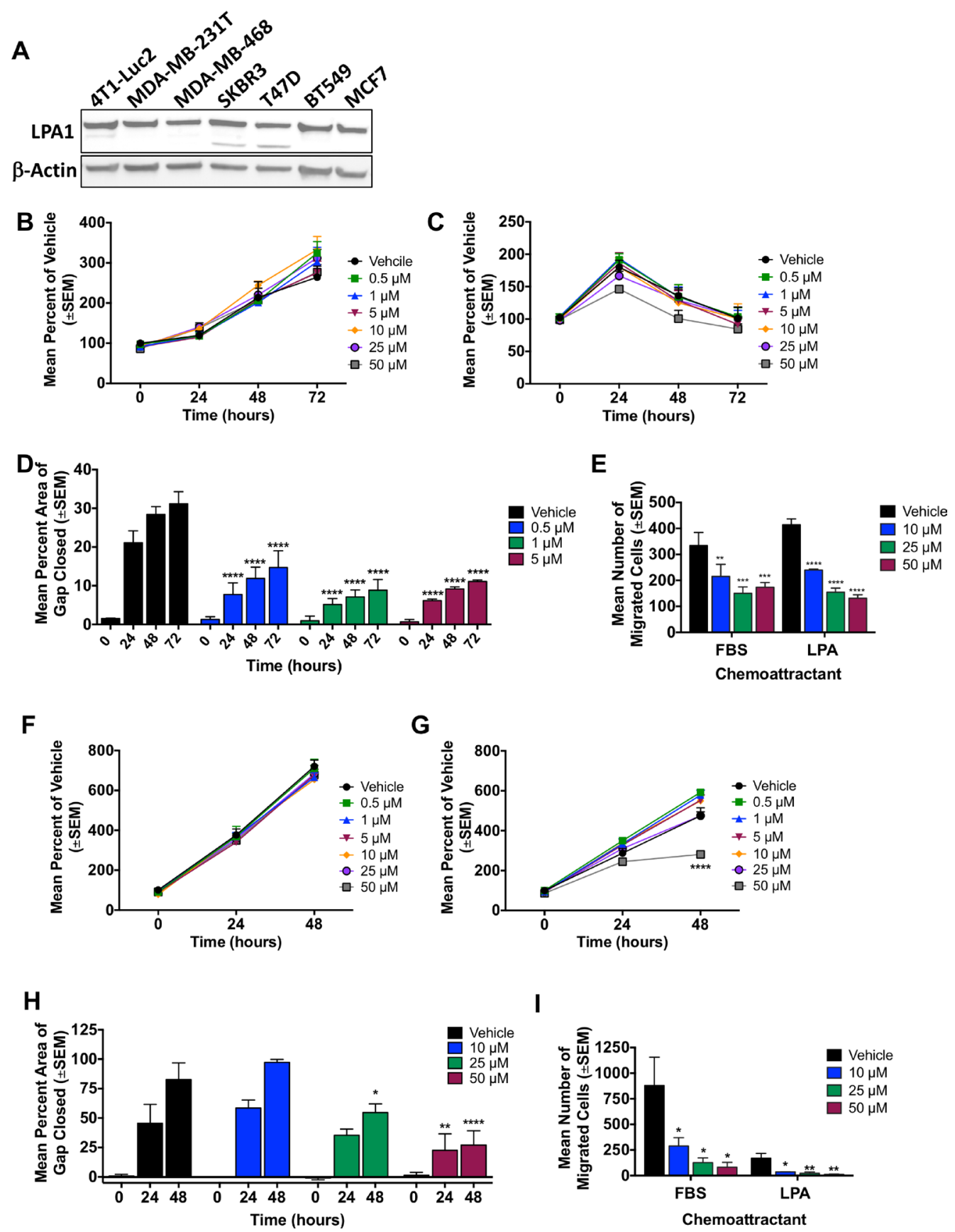

Figure 3: SAR100842 reduced migration and motility of breast cancer cell lines in vitro. (A) Western blot analysis of breast cancer cell lines for LPA1 expression with $\beta$-actin as a loading control. (B-C) Viability of human triple-negative MDA-MB-231T cells with increasing doses of SAR100842 over time in the presence of $10 \%$ serum (B) or serum-free media (C). (D) MDA-MB-231T cells were measured for the ability to migrate and close a scratch gap in a wound healing assay in the presence of vehicle or increasing concentrations of SAR100842. Percent area of gap that was closed was determined at 24,48 and 72 hours. Two-way ANOVA, $p<0.0001$ for all concentrations at all time points staring at 24 hours post scratch. (E) MDA-MB-231T cells were treated with SAR100842 for 24 hours then plated in a Boyden chamber motility assay and allowed to migrate through a collagen-coated membrane toward either $1 \%$ fetal bovine serum (FBS) or $5 \mu \mathrm{M}$ lysophosphatidic acid (LPA) for 4 hours. ANOVA, $p=0.0058, p=0.0003, p=0.0004$ for $10 \mu \mathrm{M}, 25 \mu \mathrm{M}$ and $50 \mu \mathrm{M}$ respectively to FBS. $P<0.0001$ for all concentrations to LPA. (F-G) Viability of murine 4T1-Luc2 mammary carcinoma cells with increasing doses of SAR100842 over time in the presence of 10\% serum (F) or serum free media (G). $p<0.0001$ for $50 \mu \mathrm{M}$ SAR100842 at 48 hours in serumfree media. (H) 4T1-Luc2 cells were measured for the ability to migrate and close a scratch gap in a wound healing assay in the presence of vehicle or increasing concentrations of SAR100842. Two-way ANOVA, $p=0.011$ for $25 \mu \mathrm{M}$ at 48 hours, $p=0.002$ and $p<0.0001$ for $50 \mu \mathrm{M}$ at 24 and 48 hours, respectively. (I) 4T1-Luc2 cells were treated with SAR100842 for 24 hours then plated in a Boyden chamber motility assay and allowed to migrate through a collagen coated membrane toward either $5 \%$ FBS or $10 \mu \mathrm{M} \mathrm{LPA}$ for 4 hours. ANOVA, $p=0.04, p=0.02, p=0.01$ with $10 \mu \mathrm{M}, 25 \mu \mathrm{M}$ and $50 \mu \mathrm{M}$ respectively to FBS and $p=0.02, p=0.008, p=0.007$ with $10 \mu \mathrm{M}, 25 \mu \mathrm{M}$ and $50 \mu \mathrm{M}$ respectively to LPA. All experiments repeated 3-4 times. 
In the 4T1 model, EPGN9878 treatment beginning on either day 2 or day 11 , had no effect on primary tumor size or pulmonary metastases detected in step sections (Figure 7E-7F). Staining for fibrosis of the lungs was comparable in all experimental arms (Figure 7G).

In summary, two orally available LPA1 antagonists showed in vitro activity consistent with an anti-metastatic effect, such as motility inhibition. However, in vivo metastasis preventive activity in either triple-negative breast or ovarian cancers was insufficient to justify additional translation efforts toward clinical testing. Consistent with the metastasis data, the two LPA1 antagonists had no discernable effect on tissue fibrosis.

\section{FDA approved drugs for idiopathic pulmonary fibrosis}

During the conduct of our LPA/fibrosis studies, two unrelated drugs were approved for the treatment of lung fibrosis, using respiratory capacity as the primary clinical endpoint. Nintedanib is a multi-tyrosine kinase inhibitor. In randomized trials, nintedanib significantly slowed patient declines in forced vital capacity [29]. In vitro, nintedanib significantly reduced the proliferation of MDA-MB-231T cells at concentrations of 5 and $10 \mu \mathrm{M}$ at 48 and 72 hours (Figure $8 \mathrm{~A}-8 \mathrm{~B}, p<0.0001$ ). Additionally, motility was significantly reduced $(p<0.0001)$ at the same concentrations (Figure 8C). We determined the effect of nintedanib on lung metastases in the MDA-MB-231 experimental metastasis model (Figure 9A-9B). Surface pulmonary metastases were comparable between the vehicle and nintedanib arms. A minor reduction in large metastases $(>5 \mathrm{~mm})$ was observed, from a median of 2.5 in the control arm to 0.5 in the nintedanib arm, without statistical significance $(P=0.41)$. Analysis of lung fibrosis showed no change in modified Ashcroft score, but a trend of decreased $\alpha$-SMA staining in the nintedanib treated arm (median of 35.5 in the vehicle versus 24.1 in the nintedanib arm, $P=0.24$ ).

A second approved drug for idiopathic pulmonary fibrosis is pirfenidone, also with a primary endpoint of forced vital capacity in idiopathic pulmonary fibrosis [28]. Compared to vehicle control pirfenidone did not significantly decrease the proliferation of MDA-MB$231 \mathrm{~T}$ cells. However, the vehicle did have a slight cytotoxic effect on the cells themselves when compared to untreated cells (Figure 8D-8E). Pirfenidone significantly reduced motility in a dose-dependent manner to both FBS and LPA chemoattractants (Figure 8F). In vivo, comparable numbers of pulmonary metastases were observed between vehicle and pirfenidone treated mice. A minor change in large metastases $(>5 \mathrm{~mm})$ was observed, from a median of 6 in the vehicle arm to a median of 6.5 in the pirfenidone arm, statistically insignificant $(P=0.73)$. Staining of the lung tissues for fibrosis showed no difference in the arms using trichrome stain, but a trend of increased $\alpha$-SMA staining in the pirfenidone $\operatorname{arm}(P=0.04)$.

In conclusion, neither of two FDA approved drugs for idiopathic pulmonary fibrosis was metastasis preventive in the MDA-MB-231 triple-negative model system, nor was fibrosis attenuated.
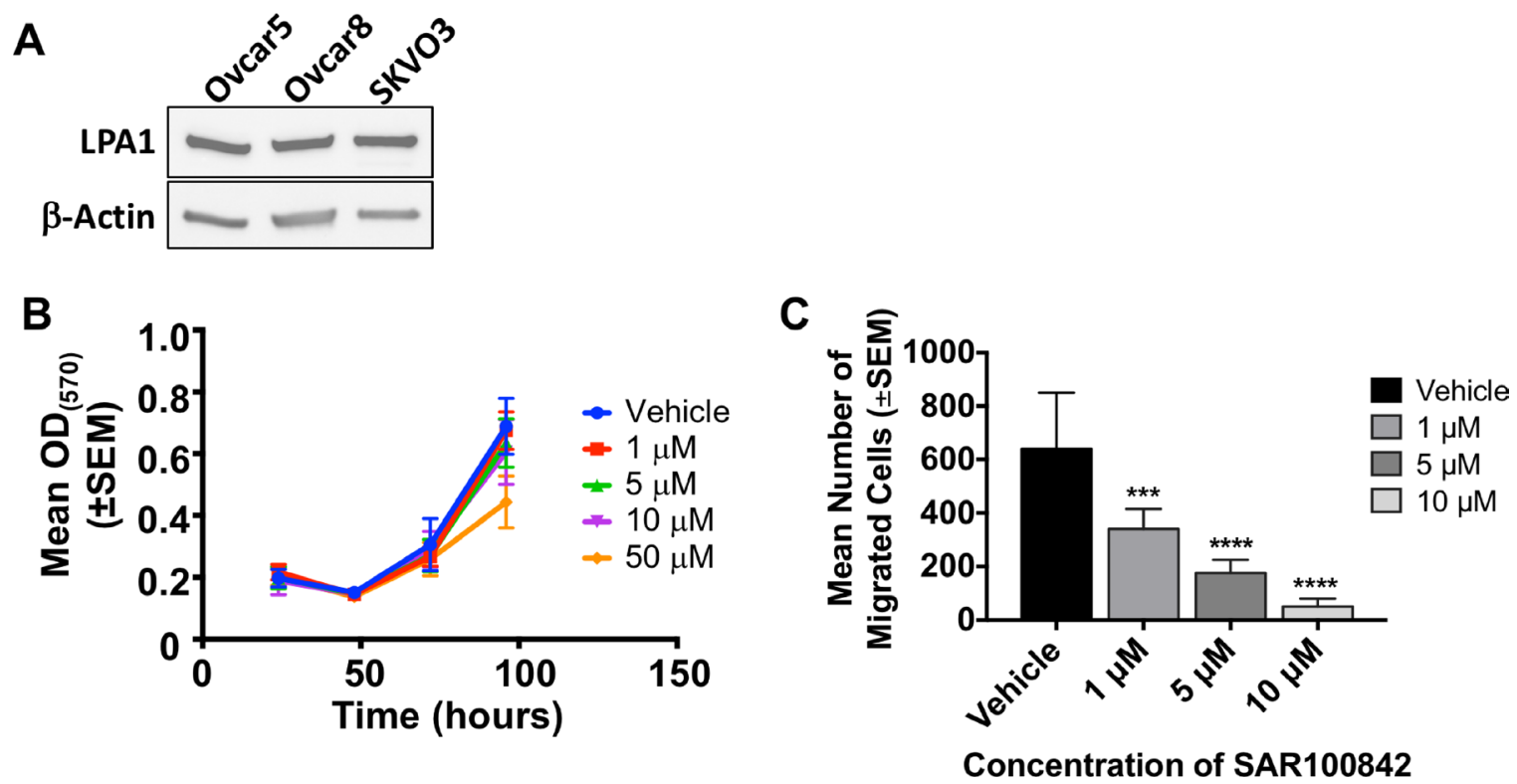

Figure 4: SAR100842 reduced motility of ovarian cancer cell lines in vitro. (A) Western blot analysis of ovarian cancer cell lines for LPAR1 expression with $\beta$-actin as a loading control. (B-C), Viability and motility of SKOV3 cells as described in legend to Figure 3. (B) Viability in $10 \%$ serum. (C) Motility toward $5 \mu \mathrm{M}$ LPA for 4 hours. ANOVA, $p=0.0006$ for $1 \mu \mathrm{M}, p<0.0001$ for 5 and $10 \mu \mathrm{M}$. All experiments repeated in triplicate. 


\section{DISCUSSION}

While fibrosis is a clear stimulant of metastasis in mouse models in which fulminant conditions are first induced, its relevance to metastasis under normal physiological conditions is less clear. We find, among multiple breast cancer model systems, focal and heterogeneously low levels of fibrosis occur in lung metastases, with heterogeneous, moderate levels in the general lung. How these data compare to breast cancer patient tissues is difficult to assess due to an inadequate literature, largely focused on primary tumors. In the
A

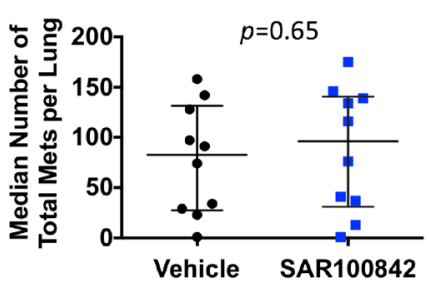

B

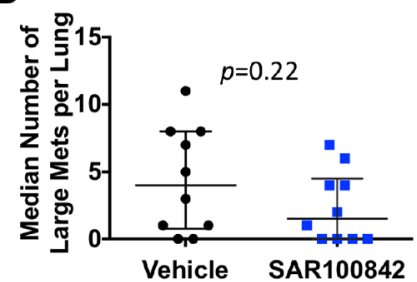

$\mathrm{E}$

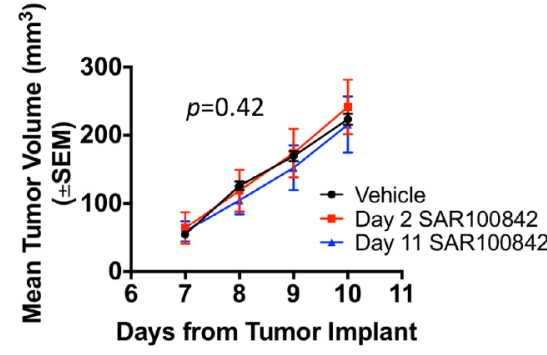

C ثै $57 \quad p=0.02$

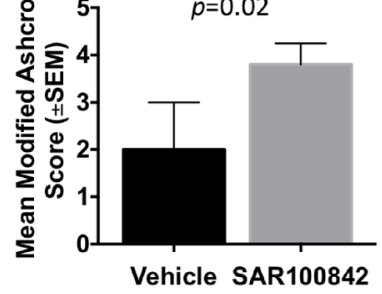

D

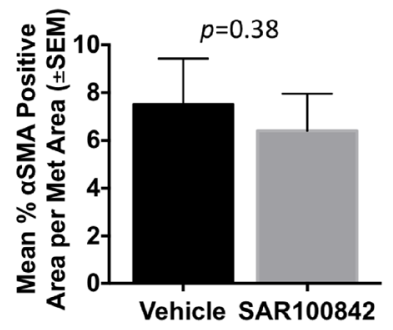

$\mathbf{F}$
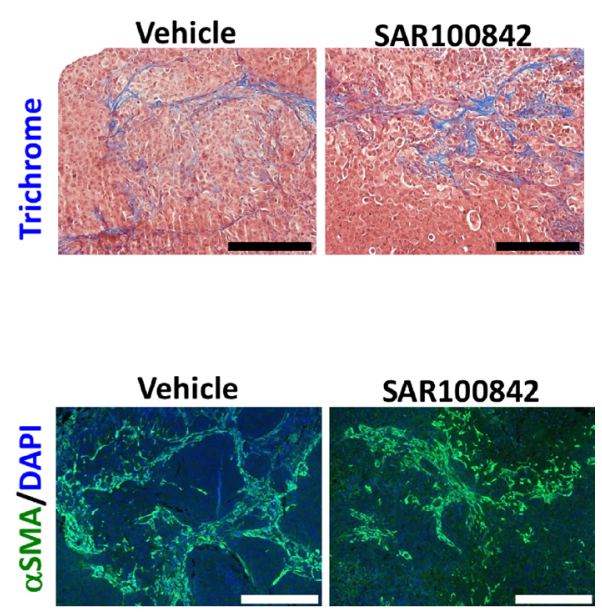
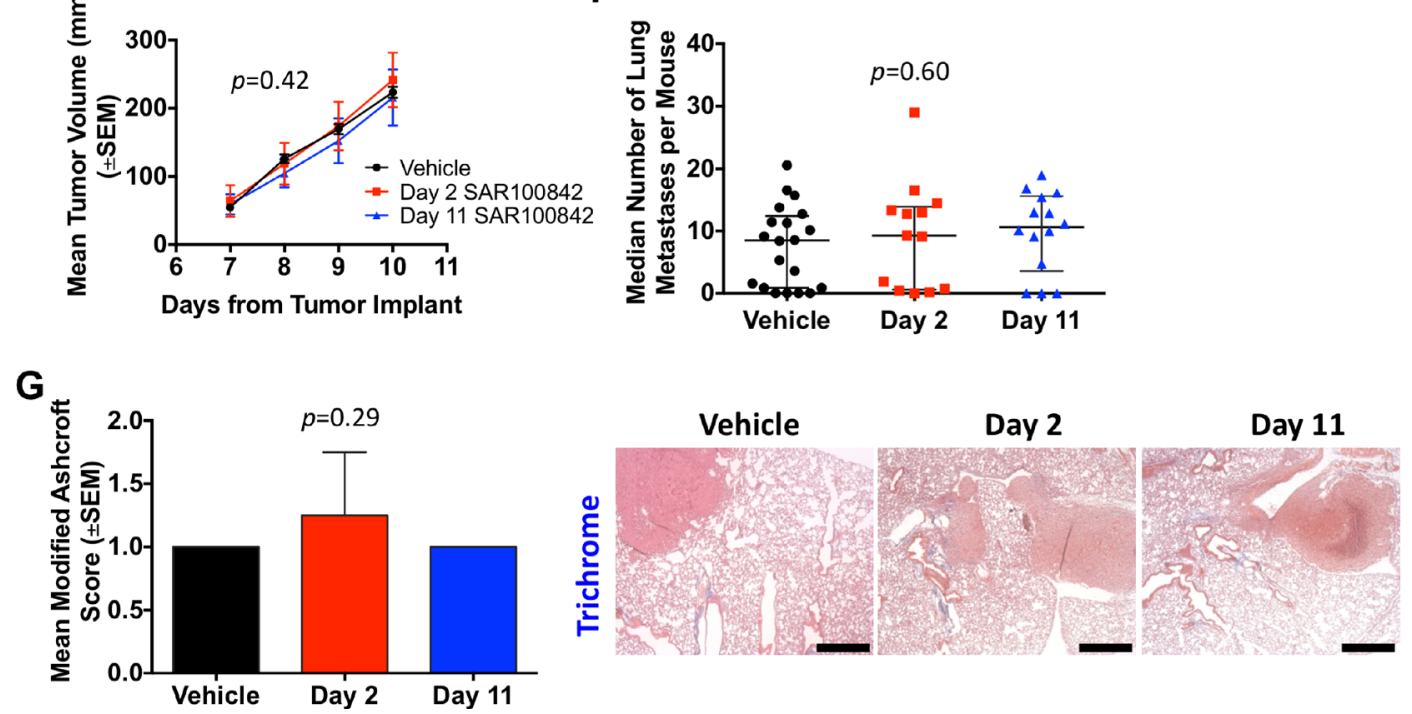

Figure 5: SAR100842 did not prevent metastases or attenuate fibrosis in two mouse models of metastatic triplenegative breast cancer. (A) Lungs bearing metastases from MDA-MB-231T cells injected in the tail vein were fixed in Bouin's solution. Surface metastases for vehicle and $30 \mathrm{mg} / \mathrm{kg}$ SAR100842 treated mice, median \pm interquartile range, Mann-Whitney $t$-test, $p=0.65$. (B) Large surface metastases were considered any metastasis lesion that measured greater than $5 \mathrm{~mm}$, median \pm interquartile range, Mann-Whitney $t$-test, $p=0.22$. (C) FFPE lungs were sectioned and stained with Masson's trichrome. The mean modified Ashcroft score from each mouse lung is plotted. $N=5$ mice per group. Images were taken at $20 \times$ objective and scale bar $=200 \mu \mathrm{m}$. Mann-Whitney $p=0.22$. (D) Lung sections were stained with $\alpha \mathrm{SMA}$. The $\alpha \mathrm{SMA}$ positive area of metastases over total metastases area in field was tabulated. $N=5$ mice per group. Images were taken at $10 \times$, scale bar $=400 \mu \mathrm{m}$. Unpaired $t$-test, $p=0.38$. (E-F) $4 \mathrm{~T} 1$-Luc2 cells were implanted into the \#4 mammary fat pad. Mice were randomized into three groups and treatment of vehicle or $30 \mathrm{mg} / \mathrm{kg}$ SAR100842 started on day 2 for groups one and two to continue through to endpoint. Tumors were palpated daily and measurements started on day 7. All groups had tumors removed in a survival surgery on day 10. (E) Primary tumor size Primary tumor size, Two-way ANOVA, $p=0.42$. On day 11, one day after primary tumor removal, group 3 began treatment with $30 \mathrm{mg} / \mathrm{kg}$ SAR100842. At endpoint of day 70, all lungs were collected. (F) The median number of lung metastases per mouse is plotted ( \pm interquartile range). $N=15-20$ mice per group. ANOVA, $p=0.60$. (G) One section representing the largest lung surface area was stained with Masson's trichrome. Fibrosis was scored in 5 fields. The mean modified Ashcroft score per mouse is plotted. $N=15-20$ mice per group. Kruskal-Wallis, $p=0.29$. Images were taken at $5 \times$ objective, scale bar $=500 \mu \mathrm{m}$. 
Table 2: Effect of SAR100842 on ovarian cancer metastasis incidence in two model systems ${ }^{\mathrm{a}}$

\begin{tabular}{|c|c|c|c|c|c|c|c|}
\hline \multirow{3}{*}{ Site: } & \multirow{3}{*}{$\begin{array}{l}\text { Lesion } \\
\text { Depth, where } \\
\text { applicable: }\end{array}$} & \multicolumn{6}{|c|}{ Fraction of mice with metastases ${ }^{\mathrm{b}}$ : } \\
\hline & & \multicolumn{3}{|c|}{ SKOV3 Model System: } & \multicolumn{3}{|c|}{ OVCAR5 Model System: } \\
\hline & & Vehicle: & $\begin{array}{l}\text { SAR100842: } \\
\text { Day } 2 \text { pi }\end{array}$ & $\begin{array}{l}\text { SAR100842: } \\
\text { Day 10 pi }\end{array}$ & Vehicle: & $\begin{array}{l}\text { SAR100842: } \\
\text { Day } 2 \text { pi }\end{array}$ & $\begin{array}{l}\text { SAR100842: } \\
\text { Day } 10 \text { pi }\end{array}$ \\
\hline Omentum & & $13 / 13$ & $10 / 10$ & $10 / 10$ & $9 / 12$ & $8 / 10$ & $7 / 10$ \\
\hline \multirow[t]{2}{*}{ Liver } & Surface & $11 / 13$ & $9 / 10$ & $9 / 10$ & $9 / 12$ & $9 / 10$ & $6 / 10$ \\
\hline & Invasive & $1 / 13$ & $0 / 10$ & $0 / 10$ & $2 / 12$ & $2 / 10$ & $1 / 10$ \\
\hline \multirow[t]{2}{*}{ Diaphragm } & Surface & $12 / 13$ & $7 / 10$ & $10 / 10$ & $7 / 12$ & $5 / 10$ & $4 / 10$ \\
\hline & Invasive & $12 / 13$ & $7 / 10$ & $10 / 10$ & $7 / 12$ & $5 / 10$ & $2 / 10$ \\
\hline \multirow[t]{2}{*}{$\begin{array}{l}\text { Lymph } \\
\text { Node }\end{array}$} & Surface & $4 / 13$ & $2 / 10$ & $3 / 10$ & $0 / 12$ & $1 / 10$ & $3 / 10$ \\
\hline & Invasive & $0 / 13$ & $0 / 10$ & $0 / 10$ & $0 / 12$ & $0 / 10$ & $0 / 10$ \\
\hline \multirow[t]{2}{*}{ Kidney } & Surface & $5 / 13$ & $1 / 10$ & $2 / 10$ & $0 / 12$ & $0 / 10$ & $0 / 10$ \\
\hline & Invasive & $0 / 13$ & $0 / 10$ & $0 / 10$ & $0 / 12$ & $0 / 10$ & $0 / 10$ \\
\hline \multirow[t]{2}{*}{ Pancreas } & Surface & $0 / 13$ & $0 / 10$ & $0 / 10$ & $7 / 12$ & $8 / 10$ & $6 / 10$ \\
\hline & Invasive & $0 / 13$ & $0 / 10$ & $0 / 10$ & $5 / 12$ & $5 / 10$ & $4 / 10$ \\
\hline \multirow[t]{2}{*}{ Peritoneal } & Surface & $13 / 13$ & $10 / 10$ & $10 / 10$ & $11 / 12$ & $9 / 10$ & $7 / 10$ \\
\hline & Invasive & $0 / 13$ & $0 / 10$ & $0 / 10$ & $0 / 12$ & $0 / 10$ & $0 / 10$ \\
\hline Ascites & & $0 / 13$ & $0 / 10$ & $0 / 10$ & $3 / 12$ & $1 / 10$ & $1 / 10$ \\
\hline
\end{tabular}

${ }^{a}$ Mice were injected intraperitoneally with either SKVO3 or OVCAR5 and treated with either vehicle or $30 \mathrm{mg} / \mathrm{kg}$

SAR100842 twice daily starting on either day 2 or day 10 post cell injection (pi). At endpoint, all organs thought to harbor tumor were fixed in $10 \%$ NBF before embedding in paraffin for sectioning and H\&E staining.

${ }^{b}$ Metastases were quantified in three sections every $200 \mu \mathrm{m}$ through each tissue, and characterized as being on the surface of the tissue or invading into the tissue, in consultation with a pathologist.

largest study, among 1850 patients undergoing two types of adjuvant therapy, central necrosis and fibrosis was only found in $3.6-4.9 \%$ of patients' primary tumors, but was strongly correlated with a triple-negative histology; central necrosis and fibrosis correlated with poor outcome [36]. Analysis of $\alpha$-SMA expression by myofibroblasts showed heterogeneity among 60 primary breast tumors, with a mean of $8.5 \%$ of tumor area positive; higher fibrosis levels correlated with poor outcome [37] . Data for untreated metastatic sites is lacking. Radiation therapy at the primary site and lymphatics is associated with local skin fibrosis and occasional reports exist for fibrosis in the underlying lungs $[38,39]$. Indications of fibrosis have been described in peritoneal masses from ovarian cancer but little quantification has been reported [40, 41]. Further data from metastatic biopsies or autopsies would be useful. It remains possible that other cancer types may have higher levels of fibrosis in metastases, such as pancreatic cancer [42] and would constitute a better therapeutic window for anti-fibrosis agents. It also remains possible that other measures of fibrosis may show more pronounced alterations.

The LPA pathway has been demonstrated to induce fibrosis [43] and antagonists have also been credentialed $[6,44]$. Our laboratories and others reported that the
LPA pathway stimulates breast $[21,45,46]$ and ovarian $[25,34,47]$ cancer metastasis, and LPAR1 antagonists significantly prevented lung, liver and bone metastasis formation [18, 48]. Metastasis formation has been ascribed to both tumor intrinsic and microenvironmental effects of the LPA pathway [49]. At the intersection of these two phenotypes, fibrosis has been reported as a "soil" for the seeding of metastases [50,51], expansion of micrometastases [16], promotion of tumor viability [10], and immune effects [17], suggesting the hypothesis that LPA-induced fibrosis may be a mechanism of metastasis promotion. This hypothesis was contrary to published data where breast cancer cells with a LPA1 knockdown were metastasis suppressed [18], suggesting a tumor cell-intrinsic effect, but did not preclude an indirect microenvironmental effect or a transdifferentiation of carcinoma cells to myoepithelial cells [11]. Testing of this hypothesis was important to both understand the biology of metastasis and explore translational avenues. Testing of LPA1 antagonists via oral gavage was considered critically important, as any clinical antagonist would need to be given on a continuous basis. Also, a clinical trial would likely enroll patients at high risk for metastasis, but where metastatic foci were not observable, the adjuvant setting. We modeled the adjuvant setting by not beginning 
drug administration immediately after initial tumor cell injection, when micrometastases were likely formed. Two orally available LPA1 antagonists (SAR100842, EPGN9878) were without significant effects on metastasis suppression or extent of fibrosis in two triple-negative breast cancer model systems. Hints of activity were observed with the reduction of large metastases using either SAR100842 or EPGN9878 in the MDA-MB-231 model system, but were not robust and failed to repeat in adjuvant setting models, where compounds were administered after micrometastases have developed.

The LPA pathway is extensively credentialed in ovarian cancer initiation and progression [25, 34, 52-55]. In gastric cancer, a connection was made between peritoneal fibrosis and peritoneal metastasis [50]. Ovarian preclinical metastasis prevention experiments were therefore conducted with SAR100842. In these experiments two cell lines were used, and produced
A

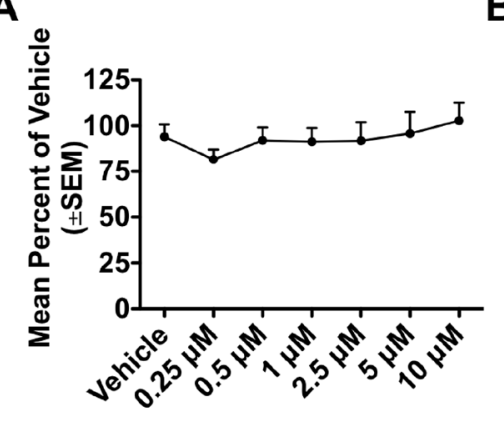

Concentration of EPGN9878
B

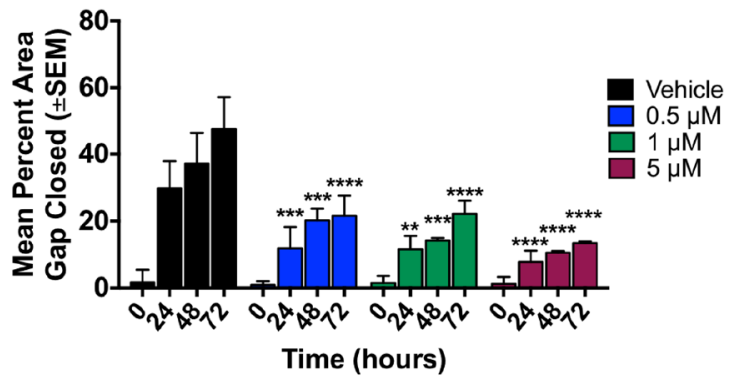

C
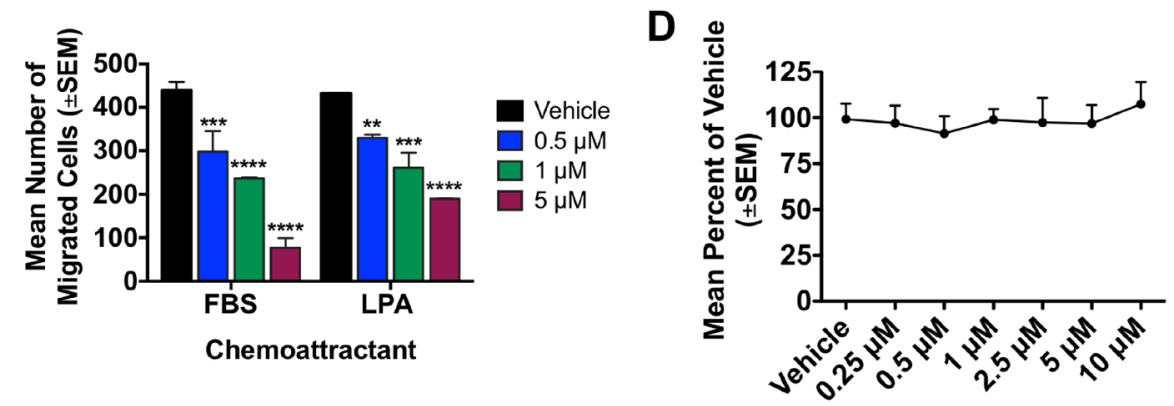

Concentration of EPGN9878
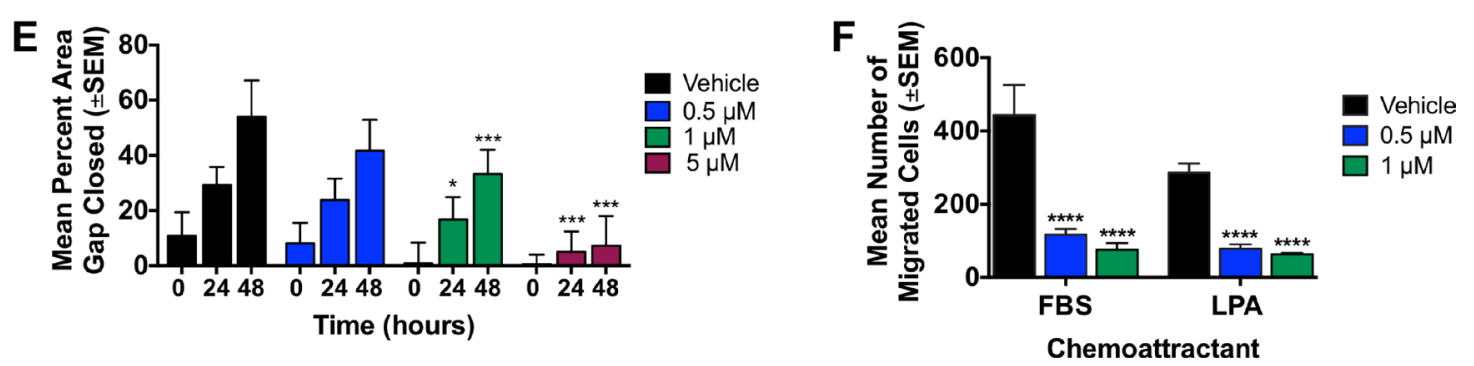

Figure 6: LPA1 antagonist, EPGN9878, reduced migration and motility of triple-negative breast cancer cell lines. Viability, motility and migration analyses were performed as described in legend to Figure 3. (A) Viability of MDA-MB-231T cells with increasing doses of EPGN9878 after 72 hours in the presence of 10\% serum. (B) Scratch wound closure of MDA-MB-231T cells in the presence of vehicle or increasing concentrations of EPGN9878. Two-way ANOVA, $p<0.005$ for all concentrations at 24 hours, $p<0.0003$ at all concentrations for 48 hours, and $p<0.0001$ at all concentrations at 72 hours. (C) MDA-MB-231T cells were treated with EPGN9878 for 24 hours then plated in a Boyden chamber motility assay and allowed to migrate through a collagen-coated membrane toward either $1 \%$ FBS or $5 \mu \mathrm{M}$ LPA for 4 hours. ANOVA, $p=0.0008, p<0.0001, p<0.0001$ for $0.5 \mu \mathrm{M}, 1 \mu \mathrm{M}$ and $5 \mu \mathrm{M}$ respectively to FBS. $P=0.006$, $p=0.0002, p<0.0001$ for $0.5 \mu \mathrm{M}, 1 \mu \mathrm{M}$ and $5 \mu \mathrm{M}$ respectively to LPA. (D) Viability of 4T1-Luc2 cells with increasing doses of EPGN9878 after 72 hours in the presence of 10\% serum. (E) 4T1-Luc2 scratch assay closure in the presence of vehicle or increasing concentrations of EPGN9878. Two-way ANOVA, $p<0.05$ with $1 \mu \mathrm{M}$ at 24 and 48 hours, $p<0.003$ with $5 \mu \mathrm{M}$ at 24 and 48 hours. (F) 4T1-Luc2 cells were treated with EPGN9878 for 24 hours then plated in a Boyden chamber motility assay and allowed to migrate through a collagen-coated membrane toward either $5 \%$ FBS or $10 \mu \mathrm{M}$ LPA for 4 hours. ANOVA, $p<0.0001$ for 1 and $5 \mu \mathrm{M}$ to both FBS or LPA. All experiments repeated 2-3 times. 
surface and invasive lesions in multiple peritoneal organs, in addition to ascites. The quantification of invasive lesions was considered important, as these are the lesions that are measured for clinical responses in trials. While the LPA pathway is extensively credentialed in ovarian cancer initiation and progression, SAR100842 was ineffective in preventing metastasis in two models suggesting that contribution of other LPARs is important in these cells beyond LPA1.

Multiple factors may contribute to these preclinical failures. The LPA1 receptor was expressed by all of the cell lines used. Both compounds demonstrated
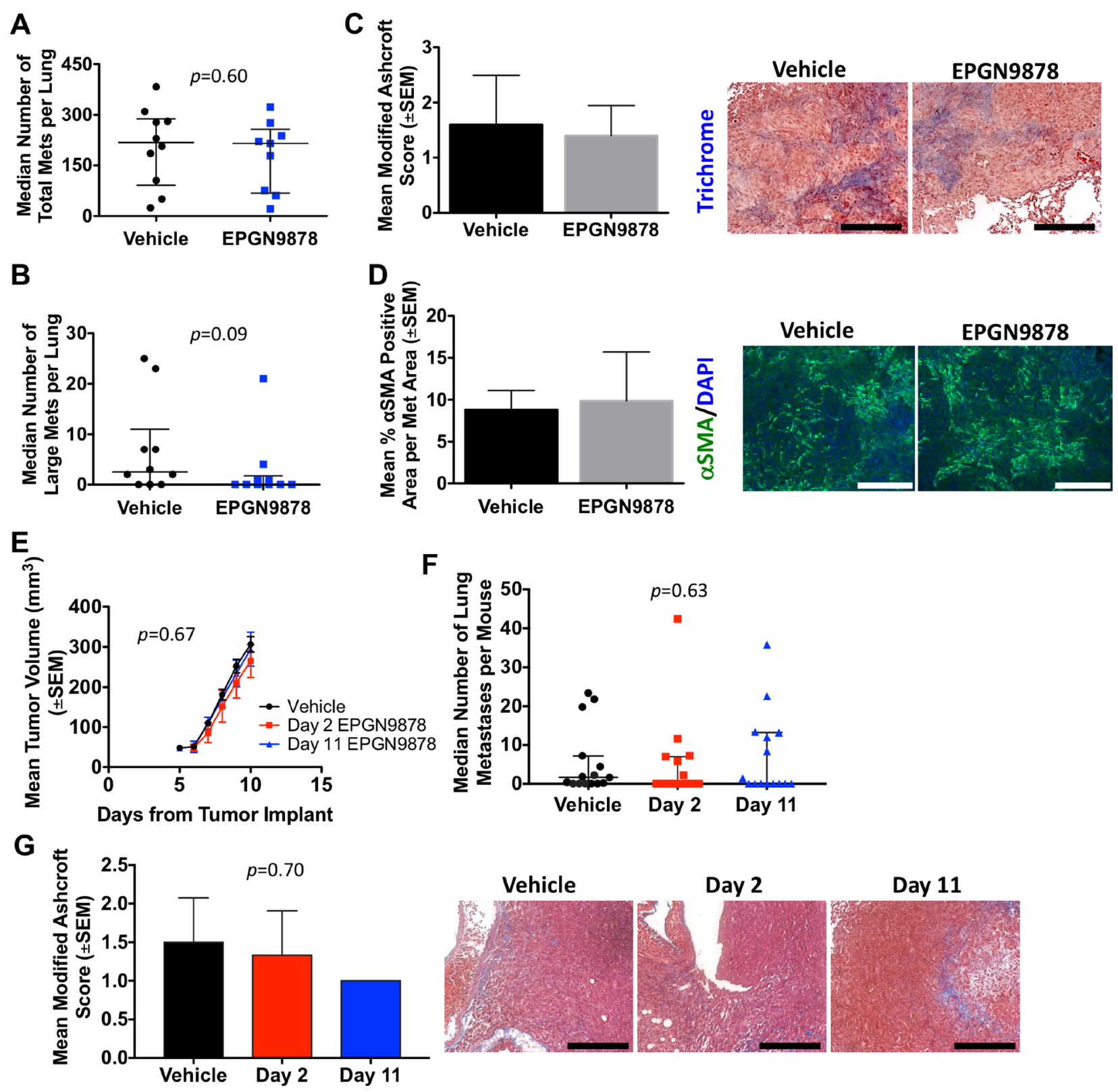

Figure 7: EPGN9878 did not prevent metastases or attenuate fibrosis in two mouse models of metastatic triple-negative breast cancer. Metastasis assays and endpoints were described in legend to Figure 5. (A) MDA-MB-231T surface metastases for vehicle and $40 \mathrm{mg} / \mathrm{kg}$ EPGN9878 treated mice. Median \pm interquartile range, Mann-Whitney $t$-test, $p=0.60$. (B) Large surface metastases, median \pm interquartile range, Mann-Whitney $t$-test, $p=0.09$. (C) FFPE lungs sections stained with Masson's trichrome. The mean Ashcroft score from each mouse lung is plotted. $N=5$ mice per group. Images were taken at $20 \times$ objective and scale bar $=200 \mu \mathrm{m}$. Mann-Whitney $p=0.99$. (D) Lung sections were stained with $\alpha$ SMA. The mean percent positive $\alpha$ SMA per metastasis area, $N=5$ mice per group. Images were taken at $20 \times$, scale bar $=200 \mu \mathrm{m}$. Unpaired $t$-test, $p=0.75$. (E) 4T1-Luc2 spontaneous metastasis assay comparing vehicle or $40 \mathrm{mg} / \mathrm{kg}$ EPGN9878 started on day 2 or 11. Primary tumor size, Two-way ANOVA, $p=0.67$. (F) The median number of lung metastases per mouse from day 70 is plotted ( \pm interquartile range). $N=15-20$ mice per group. ANOVA, $p=0.63$. (G) One section representing the largest lung surface area was stained with Masson's trichrome. The mean modified Ashcroft score per mouse is plotted. $N=15-20$ mice per group. Kruskal-Wallis, $p=0.70$. Images were taken at $20 \times$ objective, scale bar $=200 \mu \mathrm{m}$. 
a significant reduction in LPA stimulated tumor cell motility, suggesting that each compound could hit the intended target in vitro. However, further optimization of a dosing regimen based on pharmacokinetic assessment and modeling would be needed to ensure that the receptor target is blocked at all times during the study. Another orally active LPA1 antagonist was reported with preclinical activity in pancreatic cancer (which have been shown to have higher levels of fibrosis), suggesting low levels of fibrosis in breast and ovarian cancers may be responsible herein [56]. It is also known that fibrosis is mediated by a host of molecular pathways; LPA1 may only be one of many contributors. TGF- $\beta[57,58]$ and other pathways $[8,59]$ are under evaluation for fibrosis. Finally, the definition of fibrosis varies between reports. We used the trichrome clinical assay, but other labs report
A

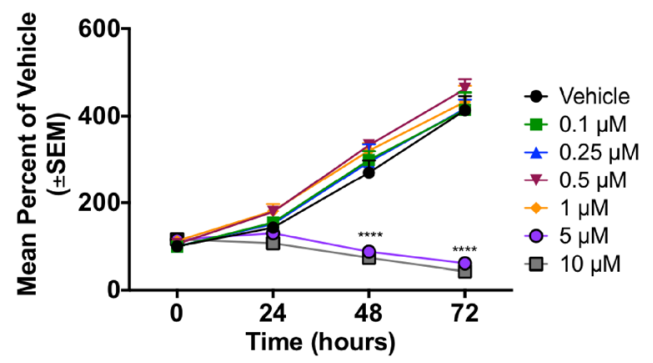

C

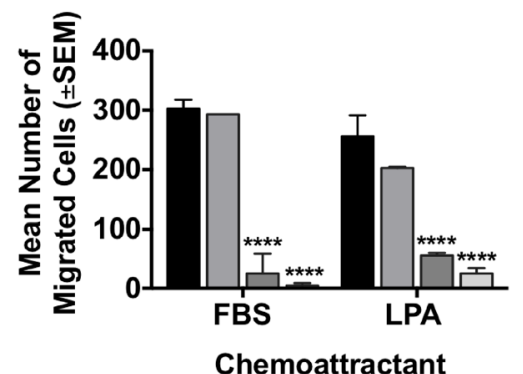

D

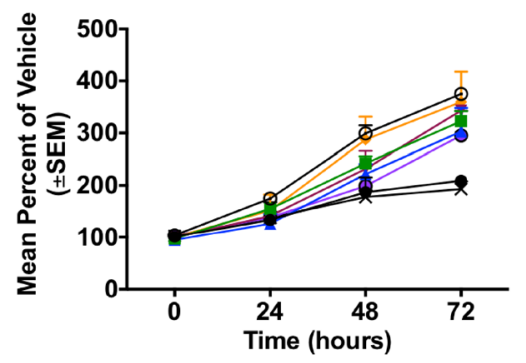

F

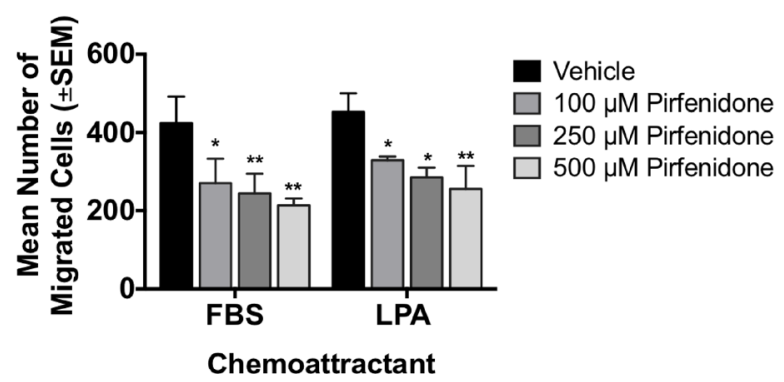

Vehicle

$1 \mu \mathrm{M}$ Nintedanib

$5 \mu \mathrm{M}$ Nintedanib

$10 \mu \mathrm{M}$ Nintedanib

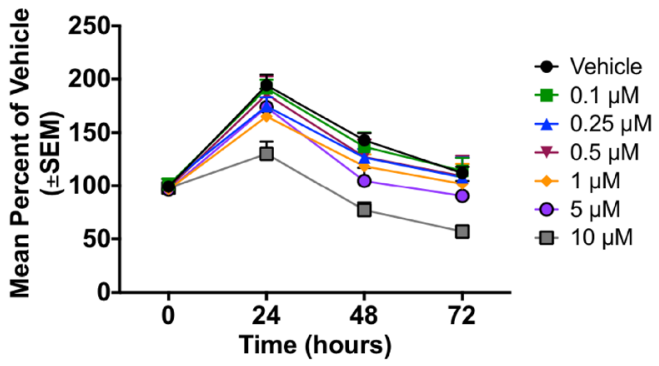

E

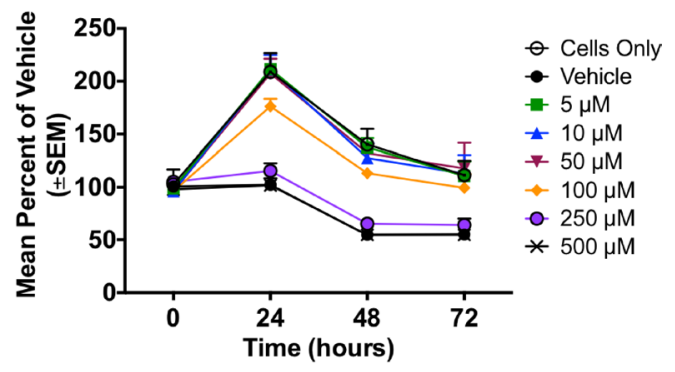

Figure 8: In vitro characterization of two idiopathic pulmonary fibrosis (IPF) drugs. (A-B) Viability of MDA-MB-231T cells with increasing doses of nintedanib over time in the presence of $10 \%$ serum (A) or serum free media (B). Two-way ANOVA, $p<0.0001$ with 5 and $10 \mu \mathrm{M}$ nintedanib at 48 and 72 hours. (C) MDA-MB-231T cells were treated with nintedanib for 24 hours then plated in a Boyden chamber motility assay and allowed to migrate through a collagen coated membrane toward either $1 \%$ FBS or $5 \mu$ M LPA for 4 hours. ANOVA, $p<0.0001$ for $5 \mu \mathrm{M}$ and $10 \mu \mathrm{M}$ to both FBS and LPA. (D-E) Viability of MDA-MB-231T cells with increasing doses of pirfenidone over time in the presence of $10 \%$ serum (D) or serum free media (E). (F) MDA-MB-231T cells were treated with pirfenidone for 24 hours then plated in a Boyden chamber motility assay and allowed to migrate through a collagen coated membrane toward either $1 \%$ FBS or $5 \mu \mathrm{M}$ LPA for 4 hours. ANOVA, $p=0.019, p=0.003, p=0.002$ for $100 \mu \mathrm{M}, 250 \mu \mathrm{M}$ and $500 \mu \mathrm{M}$, respectively to FBS. $P=0.036$, $p=0.011$, and $p=0.003$ for $100 \mu \mathrm{M}, 250 \mu \mathrm{M}$ and $500 \mu \mathrm{M}$, respectively to LPA. 

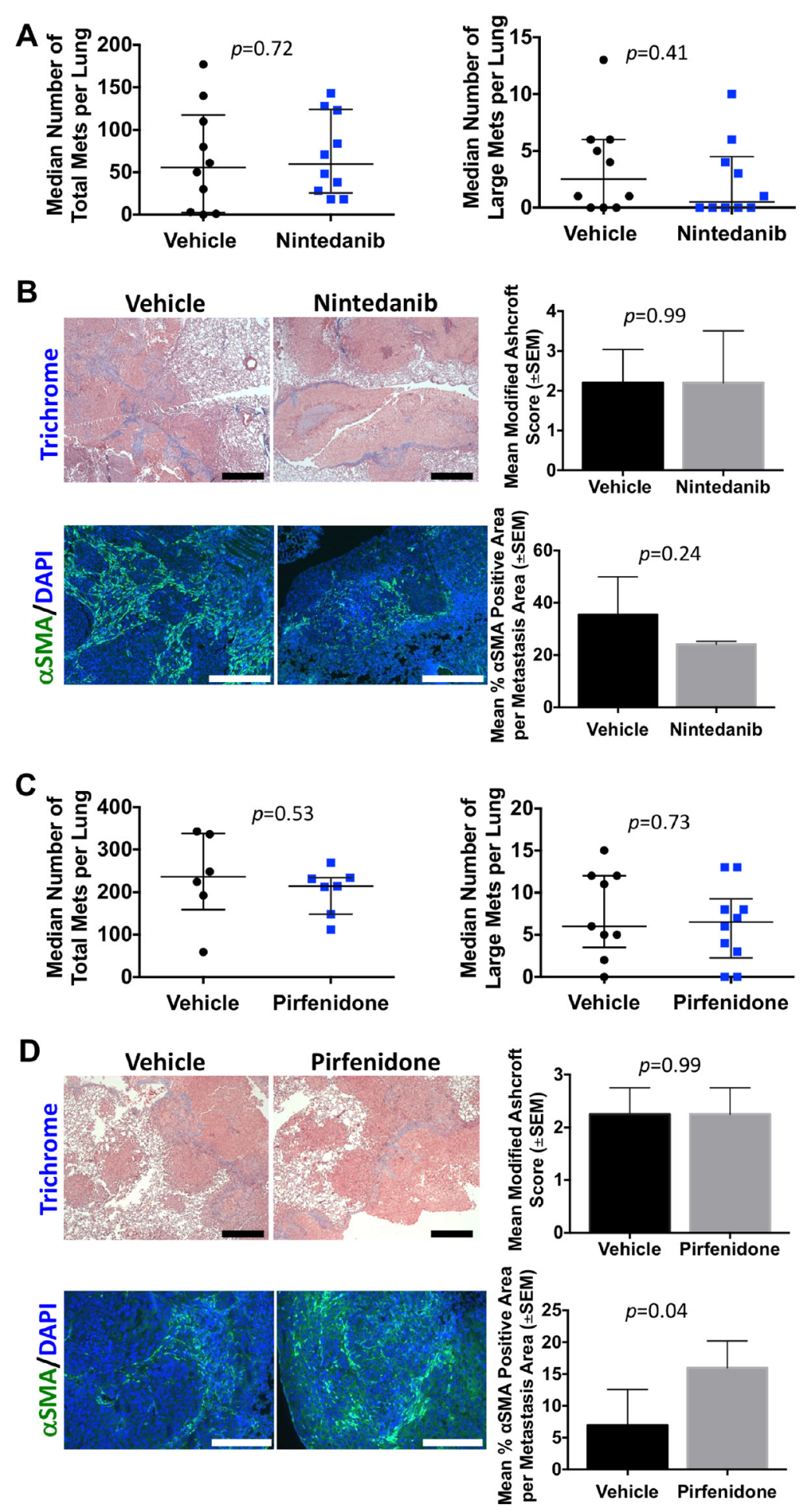

Figure 9: Lack of breast cancer metastasis prevention or attenuation of fibrosis in two drugs approved for idiopathic pulmonary fibrosis. Metastasis assays conducted as described in the legend to Figure 5. (A) MDA-MB-231T surface metastases for vehicle and $50 \mathrm{mg} / \mathrm{kg}$ nintedanib treated mice, median \pm interquartile range, Mann-Whitney $t$-test, $p=0.72$. Large surface metastases, median \pm interquartile range, Mann-Whitney $t$-test, $p=0.41$. (B) Modified Ashcroft score of FFPE lung sections, $N=5$ mice per group. Images were taken at $5 \times$ objective and scale bar $=500 \mathrm{~mm}$. Mann-Whitney $p=0.99$. Serial lung sections stained with aSMA, $N=5$ mice per group. Images were taken at $10 \times$, scale bar $=400 \mathrm{~mm}$. Unpaired $t$-test, $p=0.24$. (C) Total surface MDA-MB-231T metastases were counted for vehicle and $250 \mathrm{mg} / \mathrm{kg}$ pirfenidone treated mice. Median \pm interquartile range, Mann-Whitney $t$-test, $p=0.53$. Large surface metastases, median \pm interquartile range, Mann-Whitney $t$-test, $p=0.73$. (D) Lungs were analyzed for fibrosis using the modified Ashcroft score on trichrome stained lung sections, $N=5$ mice per group. Images were taken at $20 \times$ objective and scale bar $=200 \mathrm{~mm}$. MannWhitney $p=0.99$. Serial lung sections were stained with aSMA. The mean percent positive aSMA per met area is plotted. $N=5$ mice per group. Images were taken at $20 \times$, scale bar $=200 \mathrm{~mm}$. Unpaired $t$-test, $p=0.04$. 
that collagen crosslinking [10], TGF- $\beta$ signaling, and other aspects of fibrosis may be better therapeutic targets.

To ask the question of the relationship of fibrosis and metastasis more broadly, we investigated two drugs recently FDA approved for idiopathic pulmonary fibrosis. Nintedanib is a multi-tyrosine kinase inhibitor targeting FGFR, PDGFR and VEGFR. It was credentialed in preclinical models of lung fibrosis and systemic sclerosis and slowed the decline of forced vital capacity in idiopathic pulmonary fibrosis patients $[29,60,61]$. Pirfenidone has both anti-fibrosis and anti-inflammatory properties through incompletely defined mechanisms that may include the TGF- $\beta$ pathway and proteases. It also inhibited fibrosis preclinically and slowed the decline of forced vital capacity in patients $[28,62,63]$. Using the MDA-MB-231 triple negative breast cancer model, neither drug had significant effects on metastasis formation or extent of fibrosis. Takai et al. also studied pirfenidone in the 4T1 mouse model of triple negative breast cancer. In vitro, pirfenidone inhibited the viability and collagen production of carcinoma activated fibroblasts. In vivo, pirfenidone was without activity on tumor growth or metastasis as monotherapy, similar to our data in the MDA-MB-231 model, however an inhibition of fibrosis assayed by pico-sirius red staining was observed [64]. For both drugs, their multi-faceted mechanisms of action suggest that non-fibrosis effects may also occur, for instance inhibition of tumor cell receptor tyrosine kinase signaling. In conclusion, general anti-fibrosis drugs show little anti-metastatic activity in preclinical models and inconsistent effects on fibrosis levels.

Fibrosis may be important in other parts of breast and ovarian cancer progression such as primary tumor formation or the shedding of tumor cells. This scenario is not modeled by our preclinical experiments and would be more germane to cancer prevention trials. In both breast and ovarian cancers it is thought that tumor cell shedding can occur before patient diagnosis and surgery and is therefore not an optimal clinical trial target.

Our data suggest that, while fibrosis occurs in metastatic sites in animal models of breast and ovarian cancers, it is either insufficient or inadequately drugged to be a metastasis preventive target. The strengths of this work lie in the multiple model systems and preclinical compounds used, a reliance on the clinical assay for fibrosis, and experimental designs that attempted to mimic clinical trials. A limitation of the work is a lack of inclusion of drug and radiation therapy in the model systems. Increased fibrosis has been reported after chemotherapy with fluoropyrimidines [65], methotrexate [66] and paclitaxel [67], and radiation therapy. If greater amounts of fibrosis occur in vivo at metastatic sites, this may indicate promise for the heavily pretreated, metastatic clinical setting rather than the current experiments mimicking the adjuvant setting. We conducted two experiments using doxorubicin and paclitaxel in the
MDA-MB-231 model with inconsistent effects on lung fibrosis levels, suggesting that this will be a more complex pathway (data not shown). This is another area in which autopsy data could be insightful.

\section{MATERIALS AND METHODS}

\section{Cell lines}

Murine mammary carcinoma 4T1 luciferase-labeled (4T1-Luc2) cells (PerkinElmer, MA) were cultured in Dulbecco's modified Eagle medium (DMEM, Invitrogen, Frederick, MD) supplemented with 10\% fetal bovine serum (FBS). A subline of human MDA-MB-231 cells, designated MDA-MB-231T was generously provided by Dr. Zach Howard (Laboratory of Immunoregulation, National Cancer Institute, Bethesda, MD) and was maintained in DMEM supplemented with $10 \%$ FBS. All ovarian cancer cell lines were provided by Dr. Annunziata (Women's Malignancies Branch, National Cancer Institute, Bethesda, MD) and cultured in RPMI-1640 media (ThermoFisher Scientific) supplemented with $10 \%$ FBS.

\section{Reagents}

Lysophosphatidic acid (LPA) was purchased from Sigma-Aldrich (St. Louis, MO). Prior to use, LPA was dissolved in PBS containing 1\% fatty acid-free bovine serum albumin.

LPA1 antagonists. SAR100842 was provided by Sanofi (Paris, France) and EPGN9878 was provided by Epigen Biosciences, Inc. (San Diego, CA). Powdered stock for each was stored in the dark at $4^{\circ} \mathrm{C}$. For all in vitro experiments, SAR100842 and EPGN9878 were dissolved into $100 \%$ DMSO to $10 \mathrm{mM}$ stock and further diluted in serum free media to indicated concentrations for downstream assays. For in vivo assays, SAR100842 was obtained as a $25 \%$ nanocrystal dispersion $(\mathrm{NCD})$ at $50 \mathrm{~g} / 50 \mathrm{~mL}$ directly from Sanofi. For dosing in mice, the NCD was further diluted in a vehicle of $0.6 \%$ methylcellulose- $0.5 \%$ Tween- 80 to $3 \mathrm{mg} / \mathrm{mL}$. SAR 100842 has a half-life of $4.9 \mathrm{~h}$ and a $\mathrm{C}_{\max }$ of $5600 \mathrm{ng} / \mathrm{mL}$ after a $30 \mathrm{mg} / \mathrm{kg}$ oral dosing in mice. Mice received $30 \mathrm{mg} / \mathrm{kg}$ by oral gavage twice daily for the duration of the experiment. EPGN9878 powdered stock was dissolved to $4 \mathrm{mg} / \mathrm{mL}$ in $95: 5 \mathrm{v} / \mathrm{v} 30 \%$ captisol (SBECD) solution and dimethylacetamide (DMA). Mice received $40 \mathrm{mg} / \mathrm{kg}$ by oral gavage once daily for the duration of the experiment. The diluent for each compound was used as its vehicle control.

IPF Drugs. Nintedanib was obtained from MedKoo Biosciences (Chapel Hill, NC), pirfenidone was obtained from MedChem Express (Monmouth Junction, NJ). Nintedanib was dissolved in $100 \%$ DMSO to $10 \mathrm{mM}$ stock and pirfenidone was dissolved in $100 \%$ DMSO to $50 \mathrm{mM}$ stock, and both were diluted in serum free media for all in vitro assays. For in vivo assays nintedanib was 
suspended in $0.5 \%$ hydroxyethyl cellulose and dosed at $50 \mathrm{mg} / \mathrm{kg}$ once daily by oral gavage, and pirfenidone was suspended in $0.5 \%$ carboxymethyl cellulose and dosed at $250 \mathrm{mg} / \mathrm{kg}$ twice daily by oral gavage. For each, the vehicle was the diluent.

\section{Western blots}

Protein was extracted from all cell lines using standard RIPA buffer methods. Protein concentrations were estimated with BCA Protein Assay Kit (Thermo Scientific, Rockford, IL). SDS-Page was performed using the BioRad TGX system (Hercules, CA). Blots were blocked and incubated in primary antibody to LPA1 (Abcam) overnight, before incubation in a secondary HRP (Santa Cruz) followed by development with the Immobilon Western Chemiluminescent HRP Substrate system (EMD Millipore, Billerica, MA).

\section{In vitro functional assays}

Cellular proliferation was measured by alamarBlue cell viability assay (ThermoFisher Scientific). Cells were trypsinized for approximately 3-5 minutes, Dulbecco's modified eagle medium (DMEM) containing 10\% fetal bovine serum (FBS; Invitrogen, Carlsbad, CA) was added to neutralize the trypsin, cells were collected and counted. The cells were then plated at a density of 2,000 cells per well in a 96-well plate and allowed to attach overnight. AlmarBlue was added to cells at a 1:10 dilution in culture media and incubated at $37^{\circ} \mathrm{C}$ for 5 hours, at which time the fluorescent emission and excitation was measured on a SprectraMax M2 plate reader (Molecular Devices, Sunnyvale, CA) at $560 \mathrm{~nm}$ and $590 \mathrm{~nm}$ respectively. Cells were then treated with vehicle and increasing concentrations of drug and fluorescent readings taken at 24, 48 and 72 hours.

Cell migration assays were performed in Boyden chambers (Neuro Probe, Gaithersburg, MD) as previously described [68]. Briefly, cells were serum starved and incubated in vehicle or varying concentrations of drug for 24 hours. Lower wells contained DMEM with or without attractants (1-5\% FBS or 5-10 $\mu \mathrm{M}$ LPA). 4T1-Luc2 or MDA-MB-231T cells were added to the upper wells at a concentration of $2 \times 10^{5}$ cells $/ \mathrm{mL}$ in serum-free DMEM containing vehicle or drug and incubated for 4 hours in a humidified chamber at $37^{\circ} \mathrm{C}$ in $5 \% \mathrm{CO}_{2}$. The top chamber was removed and the cells that had migrated to the bottom of the membrane were stained using Diff Quick Staining kit (Invitrogen). Using an inverted brightfield microscope with a $10 \times$ objective, the number of cells that had migrated through the membrane was counted in three fields in the center of each filter. Each condition for all cell lines was assayed in triplicate and each experiment was independently performed three times.
For the wound healing assay, cells were plated at a concentration of 75,000 cells per well to 24-well plates in normal growth medium. Each cell line was plated in triplicate. Cells were grown for 24 hours to $100 \%$ confluence. Each well was scratched by a $1 \mathrm{~mL}$ tip in a vertical and horizontal direction to create a cross in the center of each well. After scratching, cells were washed with medium to remove the detached cells and replaced with fresh growth medium containing 1\% FBS and increasing concentrations of LPA1 antagonist. Fresh media containing antagonist was replaced daily for the duration of the experiment. The time of initial scratch was stipulated as time 0 . Pictures of scratches were taken by using phase contrast and $10 \times$ magnification at times: $0 \mathrm{~h}, 24 \mathrm{~h}, 48 \mathrm{~h}$, and $72 \mathrm{~h}$. Analysis was performed by loading images into ImageJ. Closed wound area was calculated as a percentage of area of wound at time X over area of wound at time 0 for each time point.

\section{In vivo studies}

Frederick National Laboratory is accredited by AAALAC International and follows the Public Health Service Policy for the Care and Use of Laboratory Animals. Animal care was provided in accordance with the procedures outlined in the "Guide for Care and Use of Laboratory Animals" (National Research Council; 2011; National Academies Press; Washington, D.C.).

Experiments were performed under an approved National Cancer Institute Animal Use Agreement. Female six-week-old Balb/c or Balb/c nu/nu mice were obtained from Charles River Laboratories (National Cancer Institute-Frederick Animal Production Area, Frederick, MD). In all studies, mice were weighed weekly and monitored for signs of ill health and labored breathing daily. The mice were sacrificed by being placed in a carbon dioxide chamber if pathologic conditions unrelated to the study (eg, breathing difficulties) developed or if they lost more than $20 \%$ of their starting body weight.

\section{Spontaneous metastasis mouse model}

For the spontaneous metastasis experiments, $5 \times 10^{5}$ 4T1-Luc2 cells were injected into the mammary fat pads of female Balb/c mice ( $n=15-20$ mice per group) [18]. Randomization protocol and treatment schedules were the same for all antagonists tested. On day two post cell implantation, mice were randomized to three groups. Group one began vehicle on day 2, group two began treatment on day two and group three began treatment on day 11 (one day post primary tumor resection). The primary tumors were measured beginning on day four and then daily until resection, which occurred on day 10. After 8 weeks all lungs, livers, and any other organ suspected of harboring a metastasis were collected for histologic 
analysis. Drug treatment starting on day 2 post-injection of cells was for efficacy experiments and on day 11 postinjection of cells for adjuvant experiments.

\section{Experimental pulmonary metastasis mouse model}

The experimental metastasis study was conducted using Athymic NCR nu/nu mice injected intravenously into the lateral tail vein with $7.5 \times 10^{5}$ MDA-MB-231T human breast cancer cells [18]. On the day following injection, mice were randomized into two groups containing 15 mice each receiving either vehicle or drug. The study was terminated at day 70 and the lungs and liver were harvested from each animal. For each group, ten animals had the entire lungs inflated and fixed in Bouin's solution. Surface metastatic lesions were counted on all lungs using a magnifying glass, blinded to the treatment group. Any nodule larger than $5 \mathrm{~mm}$ in diameter was counted separately as a large metastasis.

For the remaining five animals from each of the groups, the left lung lobe and the left liver lobe were fixedfrozen using a $4 \%$ PFA sucrose gradient. The remaining lung and liver tissue was fixed in 10\% NBF and switched to $70 \%$ $\mathrm{EtOH} 24$ hours later for paraffin embedding. Tissues were also used for immunofluorescence or immunohistochemical staining for expression of different proteins.

\section{Ovarian model}

To study SAR100842 in the ovarian cancer lines, 6-8 week old athymic nu/nu mice received either $1.0 \times 10^{6}$ SKVO3 cells or $3.5 \times 10^{6}$ OVCAR5 cells $(n=33$ mice per line) in an intraperitoneal injection. On day two post cell injection, mice were randomized to three groups. Group one began vehicle on day 2, group two began $30 \mathrm{mg} / \mathrm{kg}$ SAR100842 twice daily on day two for the duration of the experiment, and group three began $30 \mathrm{mg} / \mathrm{kg}$ SAR100842 twice daily on day 10 for the duration of the experiment. On day 70 post cell injection all mice were euthanized and necropsied. Liver, abdominal lymph nodes or masses, omentum, peritoneum and any other organ suspected of harboring tumor were collected, fixed in 10\% NBF and prepared for histological analysis. If present, ascites or peritoneal washings $(1 \mathrm{~mL})$ were collected and frozen.

\section{Histology}

All paraffin-embedded tissues from were sectioned on a microtome. Six micron sections were taken at two hundred micron intervals through the entirety of the tissue. Sections were subsequently stained with hematoxylin and eosin. Metastatic lesions were counted under a microscope in each section, blinded for treatment group. For the ovarian models, disease was assessed as surface (tumor attached to the tissue) or invasive (tumor invading into the tissue), and number of animals per group recorded.
Lung sections stained with Masson's trichrome (Sigma Aldrich) were quantitatively assessed for severity of fibrosis using the Ashcroft score [31]. Briefly, 4-5 random fields of view were scored from $0-8$ according to Ashcroft from sections taken from at least 5 mice per treatment or control group.

\section{Immunofluorescence}

Formalin-fixed, paraffin embedded sections of lungs were sectioned (6 micron thickness) on a microtome. A minimum of one section from each of five mice per treatment group was stained. Briefly, sections were deparaffinized in xylenes, rehydrated in alcohols, and underwent antigen retrieval (Dako). Sections were then blocked for 1 hour at room temperature in PBS containing $5 \%$ goat serum (Dako Cytomation, Carpinteria, CA). Antibodies against $\alpha$ SMA (Abcam) and collagen 1 (Col1, Millipore) were incubated overnight at $4^{\circ} \mathrm{C}$ and then sections were washed three times in PBS. Secondary polyclonal Alexa Fluor antibodies to rabbit IgG diluted at 1:500 were incubated at room temperature for 1 hour before the sections were imaged using a fluorescent microscope (Zeiss, Oberkochen, Germany). 4',6-diamidino-2phenylindole was used to stain the cell nuclei.

\section{Image analysis}

To quantitate $\alpha$ SMA positive staining, five random fields of a single lung tissue section per mouse were imaged at $10 \times$ objective. In each image, the area of metastasis was outlined and the percent of $\alpha$ SMA positive area was calculated as the area of positive fluorescent stain over total area outlined (ie: total metastasis area) using the image analysis function in Zen Imaging Software (Zeiss). The mean percent $\alpha$ SMA positive area per mouse was determined from the five fields.

\section{Statistical analysis}

Statistical analysis was conducted using Prism 4 software (Graph Pad Software, Inc.) Significance between groups was determined using Student's $t$-test, ANOVA, or two-way ANOVA depending on the assay. $P$-values lower than 0.05 were considered significant.

\section{Abbreviations}

DMA: dimethylacetamide; DMEM: Dulbecco's Modified Eagle Medium; DMSO: dimethylsufoxide; ECM, extracellular matrix; EMT: epithelial-mesenchymal transition; FBS, fetal bovine serum; H\&E: hematoxylin and eosin; IP: intraperitoneal; IPF: idiopathic pulmonary fibrosis; IV: intravenous; LPA: lysosphosphatidic acid; LPAR: lysophosphatidic acid receptor; MFP: mammary fat pad; NCD: nanocrystal dispersion; PDGF: platelet- 
derived growth factor; SMA: smooth muscle actin; TGF: transforming growth factor.

\section{Author contributions}

Danielle Brooks, experimental design and conduct, analysis of data, manuscript preparation; Alexandra Zimmer, motility experiments, analysis of data, manuscript preparation; Lalage Wakefield, provision of mouse tumor tissue blocks, analysis of data, manuscript preparation. L. Tiffany Lyle, veterinary pathology review, analysis of data, manuscript preparation; Simone Difilippantonio, mouse experiments, analysis of data, manuscript preparation; Fabio C. Tucci, provision of unpublished antagonist, analysis of data, manuscript preparation; Stephane Illiano, provision of unpublished antagonist, analysis of data, manuscript preparation; Christina Annunziata, ovarian cancer experimental design, analysis of data, manuscript preparation; Patricia S. Steeg, experimental design, data analysis and manuscript preparation.

\section{ACKNOWLEDGMENTS}

The authors thank scientists at Sanofi and Epigen Biosciences for LPA1 antagonists and dose/schedule information. The authors thank Mr. Joshua Collins for preliminary experiments.

\section{CONFLICTS OF INTEREST}

Dr. Fabio C. Tucci is an employee of Epigen Biosciences and Dr. Stephane Illiano is an employee of Sanofi.

\section{FUNDING}

This research was funded by the Intramural Program of the National Cancer Institute.

\section{REFERENCES}

1. Wynn TA. Common and unique mechanisms regulate fibrosis in various fibroproliferative diseases. The Journal of Clinical Investigation. 2007; 117:524-9.

2. Wynn TA, Ramalingam TR. Mechanisms of fibrosis: therapeutic translation for fibrotic disease. Nature Medicine. 2012; 18:1028-40.

3. Kendall RT, Feghali-Bostwick CA. Fibroblasts in fibrosis: novel roles and mediators. Frontiers in Pharmacology. 2014; 5.

4. Rybinski B, Franco-Barraza J, Cukierman E. The wound healing, chronic fibrosis, and cancer progression triad. Physiological Genomics. 2014; 46:223-44.

5. Hawinkels L, ten Dijke P. Exploring anti-TGF-ßeta beta therapies in cancer and fibrosis. Growth Factors. 2011; 29:140-52.
6. Rancoule C, Pradere JP, Gonzalez J, Klein J, Valet P, Bascands JL, Schanstra JP, Saulnier-Blache JS. Lysophosphatidic acid-1-receptor targeting agents for fibrosis. Expert Opinion on Investigational Drugs. 2011; 20:657-67.

7. Ostendorf T, Eitner F, Floege J. The PDGF family in renal fibrosis. Pediatric Neurology. 2012; 27:1041-50.

8. Hu LP, Lin XY, Lu H, Chen BC, Bai YH. An Overview of Hedgehog Signaling in Fibrosis. Molecular Pharmacology. $2015 ; 87: 174-82$.

9. Margadant $\mathrm{C}$, Sonnenberg A. Integrin-TGF-ßeta crosstalk in fibrosis, cancer and wound healing. EMBO Reports. 2010; 11:97-105.

10. Cox TR, Bird D, Baker AM, Barker HE, Ho MW, Lang G, Erler JT. LOX-Mediated Collagen Crosslinking Is Responsible for Fibrosis-Enhanced Metastasis. Cancer Research. 2013; 73:1721-32.

11. Radisky DC, Kenny PA, Bissell MJ. Fibrosis and cancer: Do myofibroblasts come also from epithelial cells via EMT? Journal of Cellular Biochemistry. 2007; 101:830-9.

12. Gong HY, Hu WG, Hu QY, Li XP, Song QB. Radiationinduced pulmonary injury accelerated pulmonary metastasis in a mouse model of breast cancer. Oncology Letters. 2015; 10:3613-8.

13. Adamson IY, Orr FW, Young L. Effects of injury and repair of the pulmonary endothelium on lung metastasis after bleomycin. The Journal of Pathology. 1986; 150:279-87.

14. Orr FW, Adamson IYR, Young L. Promotion of pulmonary metastasis in mice by bleomycin-induced endothelial injury. Cancer Research. 1986; 46:891-7.

15. Ueno H, Konishi T, Ishikawa Y, Shimazaki H, Ueno M, Aosasa S, Saiura A, Hase K, Yamamoto J. Histologic Categorization of Fibrotic Cancer Stroma in the Primary Tumor Is an Independent Prognostic Index in Resectable Colorectal Liver Metastasis. The American Journal of Surgical Pathology. 2014; 38:1380-6.

16. Higashi N, Ishii H, Fujiwara T, Morimoto-Tomita M, Irimura T. Redistribution of fibroblasts and macrophages as micrometastases develop into established liver metastases. Clinical \& Experimental Metastasis. 2002; 19:631-8.

17. Ozdemir BC, Pentcheva-Hoang T, Carstens JL, Zheng XF, Wu CC, Simpson TR, Laklai H, Sugimoto H, Kahlert C, Novitskiy SV, De Jesus-Acosta A, Sharma P, Heidari P, et al. Depletion of Carcinoma-Associated Fibroblasts and Fibrosis Induces Immunosuppression and Accelerates Pancreas Cancer with Reduced Survival. Cancer Cell. 2015; 28:831-3.

18. Marshall JC, Collins JW, Nakayama J, Horak CE, Liewehr DJ, Steinberg SM, Albaugh M, Vidal-Vanaclocha F, Palmieri D, Barbier M, Murone M, Steeg PS. Effect of Inhibition of the Lysophosphatidic Acid Receptor 1 on Metastasis and Metastatic Dormancy in Breast Cancer. J Natl Cancer Inst. 2012; 104:1306-19. 
19. Shida D, Kitayama J, Yamaguchi H, Okaji Y, Tsuno NH, Watanabe T, Takuwa Y, Nagawa H. Lysophosphatidic acid (LPA) enhances the metastatic potential of human colon carcinoma DLD1 cells through LPA1. Cancer Research. 2003; 63:1706-11.

20. David M, Wannecq E, Descotes F, Jansen S, Deux B, Ribeiro J, Serre CM, Grès S, Bendriss-Vermare N, Bollen M, Saez S, Aoki J, Saulnier-Blache JS, et al. Cancer Cell Expression of Autotaxin Controls Bone Metastasis Formation in Mouse through Lysophosphatidic AcidDependent Activation of Osteoclasts. PloS One. 2010; 5.

21. Liu SY, Umezu-Goto M, Murph M, Lu YL, Liu WB, Zhang F, Yu SX, Stephens LC, Cui XJ, Murrow G, Coombes K, Muller W, Hung MC, et al. Expression of Autotaxin and Lysophosphatidic Acid Receptors Increases Mammary Tumorigenesis, Invasion, and Metastases. Cancer Cell. 2009; 16:172.

22. Pyne NJ, Dubois G, Pyne S. Role of sphingosine 1-phosphate and lysophosphatidic acid in fibrosis. BBA Molecular and Cell Biology of Lipids. 2013; 1831:228-38.

23. Tager AM, LaCamera P, Shea BS, Campanella GS, Selman M, Zhao Z, Polosukhin V, Wain J, Karimi-Shah BA, Kim ND, Hart WK, Pardo A, Blackwell TS, et al. The lysophosphatidic acid receptor LPA links pulmonary fibrosis to lung injury by mediating fibroblast recruitment and vascular leak. Nature Medicine. 2008; 14:45-54.

24. Castelino FV, Bain G, Pace VA, Black KE, George L, Probst CK, Goulet L, Lafyatis R, Tager AM. An Autotaxin/ Lysophosphatidic Acid/Interleukin-6 Amplification Loop Drives Scleroderma Fibrosis. Arthritis Rheumatol. 2016; 68:2964-74.

25. Kim KS, Sengupta S, Berk M, Kwak YG, Escobar PF, Belinson J, Mok SC, Xu Y. Hypoxia enhances lysophosphatidic acid responsiveness in ovarian cancer cells and lysophosphatidic acid induces ovarian tumor metastasis in vivo. Cancer Res. 2006; 66:7983-90.

26. Lu ZL, Chen YJ, Hu ZD, Hu CJ. Diagnostic Value of Total Plasma Lysophosphatidic Acid in Ovarian Cancer A Metaanalysis. International Journal of Gynecological Cancer. 2015; 25:18-23.

27. Yu XC, Zhang YZ, Chen HJ. LPA receptor 1 mediates LPAinduced ovarian cancer metastasis: an in vitro and in vivo study. BMC Cancer. 2016; 16.

28. King TE, Bradford WZ, Castro-Bernardini S, Fagan EA, Glaspole I, Glassberg MK, Gorina E, Hopkins PM, Kardatzke D, Lancaster L, Lederer DJ, Nathan SD, Pereira CA, et al. A Phase 3 Trial of Pirfenidone in Patients with Idiopathic Pulmonary Fibrosis. The New England Journal of Medicine. 2014; 370:2083-92.

29. Richeldi L, du Bois RM, Raghu G. Efficacy and Safety of Nintedanib in Idiopathic Pulmonary Fibrosis. The New England Journal of Medicine. 2014; 370:2071-82.

30. Yang Y, Yang H, Hu Y, Watson P, Liu H, Geiger T, Anver M, Haines D, Martin P, Green J, Lee MP, Hunter KW,
Wakefield LM. Immunocompetent mouse allograft models for development of therapies to target breast cancer metastasis. Oncotarget. 2017; 8:30621-43. https://doi. org/10.18632/oncotarget.15695.

31. Ashcroft T, Simpson J, Timbrell V. Simple method of estimating severity of pulmonary fibrosis on a numerical scale. J Clin Pathol. 1988; 41:467-70.

32. Marino N, Marshall JC, Collins JW, Zhou M, Qian YZ, Veenstra T, Steeg PS. Nm23-H1 Binds to Gelsolin and Inactivates Its Actin-Severing Capacity to Promote Tumor Cell Motility and Metastasis. Cancer Research. 2013; 73:5949-62.

33. Khanna D, Denton CP, Jagerschmidt A, Jasson M, Distler O, Allanore Y. SAR100842, an Antagonist of Lysophaphatidic Acid Receptor 1, As a Potential Treatment for Patients with Systemic Sclerosis: Results from a Phase 2a Study. Arthritis Rheumatol. 2014; 66:S387-S.

34. Yu SX, Murph MM, Lu YL, Liu SY, Hall HS, Liu JS, Stephens C, Fang XJ, Mills GB. Lysophosphatidic Acid Receptors Determine Tumorigenicity and Aggressiveness of Ovarian Cancer Cells. J Natl Cancer Inst. 2008; 100:1630-42.

35. Ren J, Xiao YJ, Singh LS, Zhao XX, Zhao ZW, Feng L, Rose TM, Prestwich GD, Xu Y. Lysophosphatidic acid is constitutively produced by human peritoneal mesothelial cells and enhances adhesion, migration, and invasion of ovarian cancer cells. Cancer Research. 2006; 66:3006-14.

36. Maiorano E, Regan MM, Viale G, Mastropasqua MG, Colleoni M, Castiglione-Gertsch M, Price KN, Gelber RD, Goldhirsch A, Coates AS. Prognostic and predictive impact of central necrosis and fibrosis in early breast cancer: Results from two International Breast Cancer Study Group randomized trials of chemoendocrine adjuvant therapy. Breast Cancer Research and Treatment. 2010; 121:211-8.

37. Yamashita $M$, Ogawa $T$, Zhang $X$, Hanamura $N$, Kashikura Y, Takamura M, Yoneda M, Shiraishi T. Role of stromal myofibroblasts in invasive breast cancer: stromal expression of alpha-smooth muscle actin correlates with worse clinical outcome. Breast Cancer. 2012; 19:170-6.

38. Koc M, Polat P, Suma S. Effects of tamoxifen on pulmonary fibrosis after cobalt-60 radiotherapy in breast cancer patients. Radiotherapy and Oncology. 2002; 64:171-5.

39. Nishioka A, Ogawa Y, Hamada N, Terashima M, Inomata T, Yoshida S. Analysis of radiation pneumonitis and radiationinduced lung fibrosis in breast cancer patients after breast conservation treatment. Oncology Reports. 1999; 6:513-7.

40. Batista L, Gruosso T, Mechta-Grigoriou F. Ovarian cancer emerging subtypes: Role of oxidative stress and fibrosis in tumour development and response to treatment. The International Journal of Biochemistry \& Cell Biology. 2013; 45:1092-8.

41. Leinster DA, Kulbe H, Everitt G, Thompson R, Perretti M, Gavins FN, Cooper D, Gould D, Ennis DP, Lockley M, McNeish IA, Nourshargh S. The peritoneal tumour 
microenvironment of high-grade serous ovarian cancer. The Journal of Pathology. 2012; 227:136-45.

42. Whatcott CJ, Diep CH, Jiang P, Watanabe A, LoBello J, Sima C, Hostetter G, Shepard HM, Von Hoff DD, Han HY. Desmoplasia in Primary Tumors and Metastatic Lesions of Pancreatic Cancer. Clinical Cancer Research. 2015; 21:3561-8.

43. Gan L, Xue JX, Li X, Liu DS, Ge Y, Ni PY, Deng L, Lu Y, Jiang W. Blockade of lysophosphatidic acid receptors LPAR 1/3 ameliorates lung fibrosis induced by irradiation. Biochemical and Biophysical Research Communications. 2011; 409:7-13.

44. Castelino FV, Seiders J, Bain G, Brooks SF, King CD, Swaney JS, Lorrain DS, Chun J, Luster AD, Tager AM. Amelioration of Dermal Fibrosis by Genetic Deletion or Pharmacologic Antagonism of Lysophosphatidic Acid Receptor 1 in a Mouse Model of Scleroderma. Arthritis and Rheumatism. 2011; 63:1405-15.

45. Sahay D, Leblanc R, Grunewald TGP, Ambatipudi S, Ribeiro J, Clezardin P, Peyruchaud O. The LPA1/ZEB1/ miR-21-activation pathway regulates metastasis in basal breast cancer. Oncotarget. 2015; 6:20604-20. https://doi. org/10.18632/oncotarget.3774.

46. Boucharaba A, Serre CM, Gres S, Saulnier-Blache JS, Bordet JC, Guglielmi J, Clezardin P, Peyruchaud O. Plateletderived lysophosphatidic acid supports the progression of osteolytic bone metastases in breast cancer. J Clin Invest. 2004; 114:1714-25.

47. Li H, Wang DM, Zhang H, Kirmani K, Zhao ZW, Steinmetz R, Xu Y. Lysophosphatidic acid stimulates cell migration, invasion, and colony formation as well as tumorigenesis/metastasis of mouse ovarian cancer in immunocompetent mice. Molecular Cancer Therapeutics. 2009; 8:1692-701.

48. Boucharaba A, Serre CM, Guglielmi J, Bordet JC, Clezardin P, Peyruchaud O. The type 1 lysophosphatidic acid receptor is a target for therapy in bone metastases. Proc Natl Acad Sci U S A. 2006; 103:9643-8.

49. Lee SC, Fujiwara Y, Liu JX, Yue JM, Shimizu Y, Norman DD, Wang YH, Tsukahara R, Szabo E, Patil R, Banerjee S, Miller DD, Balazs L, et al. Autotaxin and LPA(1) and LPA(5) Receptors Exert Disparate Functions in Tumor Cells versus the Host Tissue Microenvironment in Melanoma Invasion and Metastasis. Molecular Cancer Research. 2015; 13:174-85.

50. Yashiro M, Chung YS, Nishimura S, Inoue T, Sowa M. Fibrosis in the peritoneum induced by scirrhous gastric cancer cells may act as "soil" for peritoneal dissemination. Cancer. 1996; 77:1668-75.

51. Zhang C, Wu MZ, Zhang LZ, Shang LR, Fang JH, Zhuang SM. Fibrotic microenvironment promotes the metastatic seeding of tumor cells via activating the fibronectin $1 /$ secreted phosphoprotein 1 -integrin signaling.
Oncotarget. 2016; 7:45702-14. https://doi.org/10.18632/ oncotarget.10157.

52. Mukherjee A, Ma YB, Yuan F, Gong YL, Fang ZY, Mohamed EM, Berrios E, Shao HJ, Fang XJ. Lysophosphatidic Acid Up-Regulates Hexokinase II and Glycolysis to Promote Proliferation of Ovarian Cancer Cells. Neoplasia. 2015; 17:723-34.

53. Fan QP, Cai QC, Xu Y. FOXM1 is a downstream target of LPA and YAP oncogenic signaling pathways in high grade serous ovarian cancer. Oncotarget. 2015; 6:27688-99. https://doi.org/10.18632/oncotarget.4280.

54. Dutta S, Wang FQ, Wu HS, Mukherjee TJ, Fishman DA. The NF-kappa B pathway mediates lysophosphatidic acid (LPA)-induced VEGF signaling and cell invasion in epithelial ovarian cancer (EOC). Gynecologic Oncology. 2011; 123:129-37.

55. Seo EJ, Kwon YW, Jang IH, Kim DK, Lee SI, Choi EJ, Kim KH, Suh DS, Lee JH, Choi KU, Lee JW, Mok HJ, Kim KP, et al. Autotaxin Regulates Maintenance of Ovarian Cancer Stem Cells through Lysophosphatidic Acid-Mediated Autocrine Mechanism. Stem Cells. 2016; 34:551-64.

56. Komachi M, Sato K, Tobo M, Mogi C, Yamada T, Ohta H, Tomura H, Kimura T, Im DS, Yanagida K, Ishii S, Takeyoshi I. Okajima F. Orally active lysophosphatidic acid receptor antagonist attenuates pancreatic cancer invasion and metastasis in vivo. Cancer Science. 2012; 103:1099-104.

57. Kim MJ, Park SA, Kim CH, Park SY, Kim JS, Kim DK, Nam JS, Sheen YY. TGF-ßeta Type I Receptor Kinase Inhibitor EW-7197 Suppresses Cholestatic Liver Fibrosis by Inhibiting HIF1 alpha-Induced Epithelial Mesenchymal Transition. Cellular Physiology and Biochemistry. 2016; 38:571-88.

58. Flechsig P, Dadrich M, Bickelhaupt S, Jenne J, Hauser K, Timke C, Peschke P, Hahn EW, Gröne HJ, Yingling J, Lahn M, Wirkner U, Huber PE. LY2109761 Attenuates Radiation-Induced Pulmonary Murine Fibrosis via Reversal of TGF- $\beta$ eta and BMP-Associated Proinflammatory and Proangiogenic Signals. Clinical Cancer Research. 2012; 18:3616-27.

59. Getachew Y, Cusimano FA, Gopal P, Reisman SA, Shay JW. The Synthetic Triterpenoid RTA 405 (CDDO-EA) Halts Progression of Liver Fibrosis and Reduces Hepatocellular Carcinoma Size Resulting in Increased Survival in an Experimental Model of Chronic Liver Injury. Toxicological Sciences. 2016; 149:111-20.

60. Wollin L, Maillet I, Quesniaux V, Holweg A, Ryffel B. Antifibrotic and Anti-inflammatory Activity of the Tyrosine Kinase Inhibitor Nintedanib in Experimental Models of Lung Fibrosis. J Pharmacol Exp Ther. 2014; 349:209-20.

61. Huang JG, Beyer C, Palumbo-Zerr K, Zhang Y, Ramming A, Distler A, Gelse K, Distler O, Schett G, Wollin L, Distler JH. Nintedanib inhibits fibroblast activation and ameliorates 
fibrosis in preclinical models of systemic sclerosis. Ann Rheum Dis. 2016; 75:883-90.

62. Meier R, Lutz C, Cosin-Roger J, Fagagnini S, Bollmann G, Hunerwadel A, Mamie C, Lang S, Tchouboukov A, Weber FE, Rogler G, Hausmann N. Decreased Fibrogenesis After Treatment with Pirfenidone in a Newly Developed Mouse Model of Intestinal Fibrosis. Inflammatory Bowel Diseases. 2016; 22:569-82.

63. Yu WC, Guo F, Song XX. Effects and mechanisms of pirfenidone, prednisone and acetylcysteine on pulmonary fibrosis in rat idiopathic pulmonary fibrosis models. Pharmaceutical Biology. 2017; 55:450-5.

64. Takai K, Le A, Weaver VM, Werb Z. Targeting the cancerassociated fibroblasts as a treatment in triple-negative breast cancer. Oncotarget. 2016; 7:82889-901. https://doi. org/10.18632/oncotarget.12658.

65. Fata F, Ron IG, Maluf F, Klimstra D, Kemeny N. Intraabdominal fibrosis after systemic and intraperitoneal therapy containing fluoropyrimidines. Cancer. 2000; 88:2447-51.

66. Ohbayashi M, Kubota S, Kawase A, Kohyama N, Kobayashi Y, Yamamoto T. Involvement of epithelialmesenchymal transition in methotrexate-induced pulmonary fibrosis. The Journal of Toxicological Sciences. 2014; 39:319-30.

67. Tsukada T, Fushida S, Harada S, Terai S, Yagi Y, Kinoshita J, Oyama K, Tajima H, Ninomiya I, Fujimura T, Ohta T. Low-dose paclitaxel modulates tumour fibrosis in gastric cancer. International Journal of Oncology. 2013; 42:1167-74.

68. Horak CE, Lee JH, Elkahloun AG, Boissan M, Dumont S, Maga TK, Arnaud-Dabernat S, Palmieri D, StetlerStevenson WG, Lacombe ML, Meltzer PS, Steeg PS. Nm23-H1 suppresses tumor cell motility by downregulating the lysophosphatidic acid receptor EDG2. Cancer Res. 2007; 67:7238-46. 